Portland State University

PDXScholar

1971

\title{
François Pierre Guillaume Guizot: an intellectual approach
}

\author{
Elbert Hardy Cave \\ Portland State University
}

Follow this and additional works at: https://pdxscholar.library.pdx.edu/open_access_etds

Part of the European History Commons, Intellectual History Commons, and the Political History Commons

Let us know how access to this document benefits you.

\section{Recommended Citation}

Cave, Elbert Hardy, "François Pierre Guillaume Guizot: an intellectual approach" (1971). Dissertations and Theses. Paper 1467.

https://doi.org/10.15760/etd.1466

This Thesis is brought to you for free and open access. It has been accepted for inclusion in Dissertations and Theses by an authorized administrator of PDXScholar. Please contact us if we can make this document more accessible: pdxscholar@pdx.edu. 
AN ABSTRACT OF THE THESIS OF EIbert Hardy Cave for the Master of Arts in History presented May 4, 1971.

Title: François Pierre Guillaume Guizot: An Intellectual Approach

APPROVED BY MEMBERS OF THE THESIS COMITTEE:

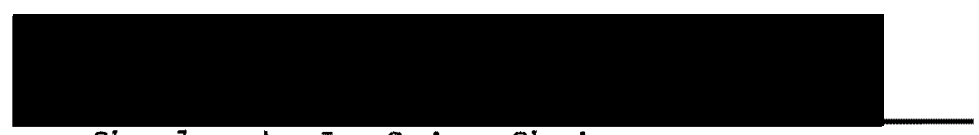

Charles A. Le Guin, Chairman

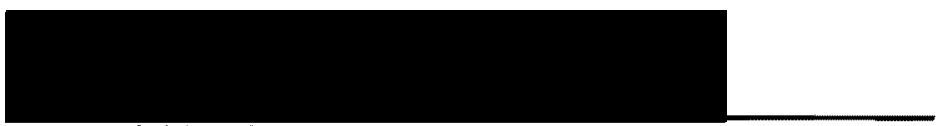

Franklin C. West

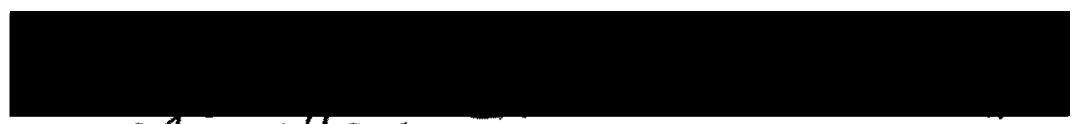

Geprge Af Carbone

The problem of this study was to present an intellectual picture of a man who is too often written off as a mere politician and a failure at that.

In approaching the problem, his works were used heavily, though availability was a problem. François Guizot, the man studied, wrote profusely, on a large variety of subjects, including philosophy, religion, history, political theory, and education. All of these areas were covered in the study. His private papers and correspondence are, for the most part, unpublished, though the eight volumes of his Mémoires were extremely helpful.

There are many good biographical studies of Guizot, though few of them approach him from an intellectual viewpoint. One of the few that does, by Sister Mary Consolata O'Connor, is not sufficient.

The conclusion of the present study is that Guizot is an excellent representative of liberal French bourgeois thought, especially in the 
first half of the nineteenth century, who is too often written off as a reactionary or, as Douglas Johnson says, a mere frustrated politician. 
FRANÇOIS PIERRE GUILLAUME GUIZOT: AN INTELIECTUAL APPROACH

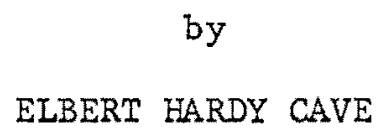

A thesis submitted in partial fulfillment of the requirements for the degree of

MASTER OF ARTS

in

HISTORY

Portland State University

1971 
TO THE OFFICE OF GRADUATE STUDIES:

The members of the Committee approve the thesis of

Elbert Hardy Cave presented May 4, 1971.

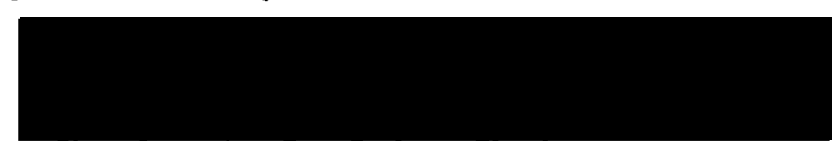

Charles A. Le Guin, Chairman

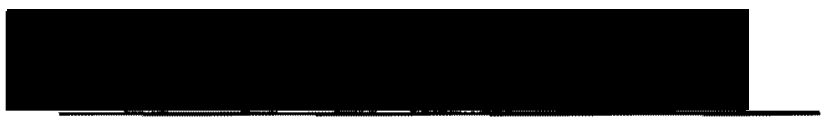

Franklin C. West

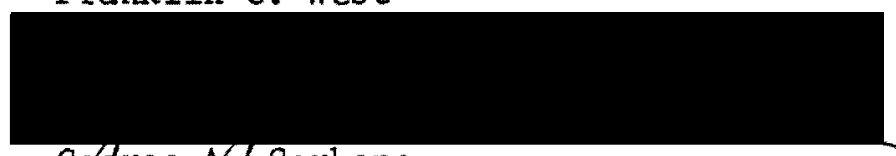

Gefrge A. Carbone

$1 /$

APPROVED :

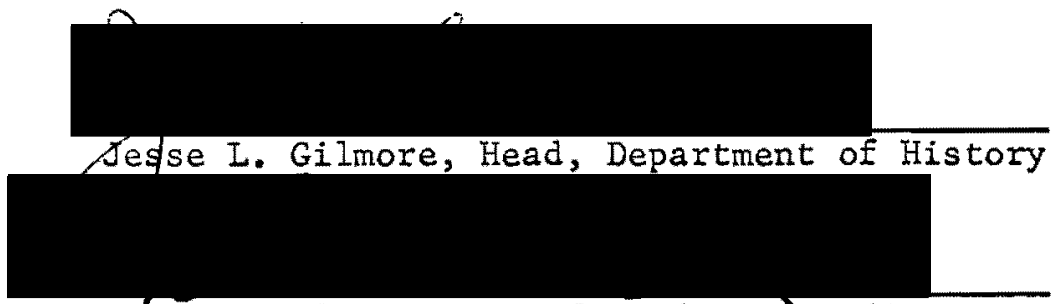

David T. Clark, Dean of Graduate \$tudies 
TABLE OF CONTENTS

PAGE

CHAPTER

I INTRODUCTION .................

II CIVILIZATION ................

III REFORMATION, REVOLUTION, AND REACTION . . . .

IV IIBERTY AND ORDER ................

V PHILOSOPHY AND RELIGION ...........

BIBIIOGRAPHY ..................... 
CHAPTER I

\section{INTRODUCTION}

Nineteenth century Europe has been characterized by one scholar as the triunph of the middle classes. 1 François Pierre Guillaume Guizot made the same evaluation early in that century, without the aid of any historical perspective enjoyed by modern scholars. It is essentially because Guizot represented many of the intellectual attitudes of the educated bourgeoisie in France that this study of his thought has been made. It is not primarily concerned with Guizot as a politician, although that aspect of his career is extremely important. It has been well portrayed already. ${ }^{2}$ This examination is directed toward Guizot as an historian, a thinker, a religious man (a Protestant in a Catholic country), and a "liberal conservative," as he characterized his own conduct while Minister of Education. ${ }^{3}$ As Douglas Johnson has put it, "If his historical work has been remembered, and if his theological work is sometimes recalled, these intellectual preoccupations are

ICharles Morazé, The Triumph of the Middle Classes: A Political and Social History of Europe in the Nineteenth Century, translated by George Weidenfeld and Nicolson Ltd. (Garden City, New York: Doubleday \& Company, Inc., 1966).

2 See Robert Louis Koepke, "Francois Guizot and the Formation of a Conservative Party in France, 1840-48," unpublished dissertation (Stanford: 1967); Douglas Johnson, Guizot: Aspects of French History 17871874 (London: Routledge \& Kegan Paul, 1963).

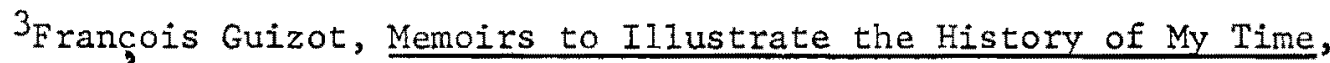
translated by J.W. Cole, Esq. (8 vols; London: Richard Bentley, 1858), III, 105. 
usually thought of as irrelevant to his career as a statesman, and it is customary to think of Guizot essentially as an unsuccessful politician. 14 This is unfortunate both because it is a distortion of Guizot as a man and because by ignoring Guizot's intellectual ideas, a good source of bourgeois ideology in the first half of the nineteenth century is neglected.

Guizot was by accident of birth a Protestant. He was born in Nîmes on October 4, 1787. His grandfather had been a Protestant pastor and his father was a liberal lawyer. At the age of seven Guizot lost his father to the Terror, an event which was the basis of his life-long aversion to violence. The family's land was temporarily confiscated, and as a result they went to Geneva in 1799 . Guizot spent the period 1799 to 1805 studying in Geneva. This period was a crucial one for his intellectual development. His daughter wrote that "Les annees lat Geneva7 s'écoulaient ainsi, activement et utilement remplies, si austères dans leur consecration au travail et du devoir, que l'empreinte en devait durer autant que la vie de M. Guizot."5 While at Geneva, he was exposed to foreign languages and studies which broadened his outlook, at a time when most of France was enraptured by Napoleon and nationalism. The result was that Guizot was looked upon by Frenchmen of that period as un-French to a large degree. Guizot realized this and in his personal political career it was almost as much of a handicap as was his Protestantism. Intellectually, it was a blessing, and this

4 Johnson, Guizot, p. 11.

5Mme. Guizot de Witt, Monsieur Guizot dans sa famille et avec ses amis (Paris: Librairie Hachette et cie, 1880), p. 12 . 
Guizot realized as wel1. In 1808 he wrote to a former teacher that "there is nothing more advantageous than forcing the French to go and find amongst foreigners what they vainly look for among themselves." 6

In that same year, Guizot began his translation and editing of Gibbon, having studied law in Paris from 1805 to 1807 before deciding against a legal career. He was isolated from Imperial society in Paris. In 1806 he wrote to his mother that, "si je me t'écrivais pas, je serais inquiet, malheureux; tu es la seule persone a que j'ouvre mon âme sans crainte."7 His work on Gibbon brought him to the attention of the men of letters, opening a channel for the release of his enormous energy and considerable talents. His Genevan training continued to show. He later wrote that during his early residence in Paris, "German metaphysics and literature were] my favourite study; I read Kant and Klopstock, Herder and Schiller, much more frequently than Condillac and Voltaire. "18

It was on an intellectual level that Guizot met his first wife, Pauline de Meulan. He had read some of her articles and seen her a few times, when he learned that she had fallen ill and could not write. He offered to write for her until she recovered, and she accepted. Their correspondence, wrote their daughter, "témoigne en effet du progres constant de leur intimité intellectuelle comme de leur affection

6Quoted by Johnson, Guizot, p. 21, uncited. 7 de Witt, Dans sa famille, pp. 14-15.

8Guizot, Memoirs, I, 8. For Guizot's early life see Charles-H. Pouthas, La jeunesse de Guizot (1787-1814) (Paris: Librairie Felix Alcan, 1936). 
reciproque." In 1811, Guizot and Pauline de Meulan began publishing the Annales de l'éducation. One year later they married. In that same year Guizot began lecturing on history at the Sorbonne. In 1814, publication of the Annales ceased, and Guizot began his political career as secretary-general in the Ministry of the Interior.

Guizot welcomed the Restoration, and during the Hundred Days he accepted a mission from Paris Royalists to Louis XVIII. The mission is of little historical importance except for its reinforcement of Guizot's royalist preferences. In 1820 , the duc de Berry was assassinated, and two years later Guizot's lectures were halted as a result of the royalist reaction. By this time Guizot was linked with a number of other liberal intellectuals:

It is in the Restoration that a host of young Liberal professors emerge to confront the Conservative coalition with a liberal history. Guizot, Trognon, Villemain, and Cousin are the idols of the young generation of students as well as public figures. In fact, there is no better barometer of Restoration politics than the presence or absence in the universities of Liberal professors. The expulsion of Guizot and Cousin in 1822 marked a new phase of Restoration reaction. Their triumphant return in 1828 was the measure of Liberal victory. 10

Guizot's lectures of 1828 at the Sorbonne became his History of Civilization in Europe, which G. P. Gooch considered "an enormous advance in the interpretation of history." This work, more than any other he produced, embodies the liberal bourgeois mentality:

Guizot7 sweeps the field as from a lofty watch-tower. His eyes are on the distant horizon and the collective achievement. His philosophy of history is an unshakeable belief in Providence,

${ }^{9}$ de Witt, Dans sa famille, p. 44.

10 Stanley Mellon, The Political Uses of History--A Study of Historians in the French Restoration (Stanford: Stanford University Press, 1958), p. 2 . 
but the transfomations of society are explained on purely secular grounds. The influence of individuals, however, and the chapter of accidents are underestimated, and the epochs dovetail too neatly into one another. There is peril in mingling with the crowd, but there is also danger in surveying the changes and chances of mortal life from the sumit of olympus. 11

Both Mellon and, to a lesser degree, Gooch, accused Guizot of using history as a tool for political propaganda. Guizot realized such charges would be made, and in his Memoires he disclaimed any political intentions. "I scrupulously restrained myself within the sphere of general ideas and by-gone facts. Intellectual independence is the natural privilege of science."12 Douglas Johnson takes the opposite view from Mellon and Gooch. Merely because "many historians were active in politics and because their works either had, or were attributed, a political significance, it does not mean that history had become a mere province of politics." It is ridiculous, he continues, "to think of Guizot working through Gregory of Tours or Whitelock's Memorials in order to further his opposition to Villele's ministry." To dismiss the "great advance in the conception and technique of historical research which took place in these years as being incidental to political controversy is seriously to misrepresent an important intellectual

$11_{G}$. P. Gooch, History and Historians in the Nineteenth Century (Boston: Beacon Press, 1959), p. 180. Guizot's contemporary and sometime rival, Michelet, saw the danger of surveying from the sumit, but denied the danger of mingling with the drowd. In the introduction to The People, he wrote, "Let it be my part in the future to have not attained, but marked, the aim of history, to have called it by a name that nobody had given it. Thierry called it narration, and $M$. Guizot analysis. I have named it resurrection, and this name will remain." The Varieties of History from Voltaire to the Present, ed. by Fritz Stern (Cleveland: The World Publishing Company, 1956), p. 117.

12Guizot, Memoirs, I, 299-300. 
movement."13 Both camps seem to ignore a more reasonable middle ground. Johnson ignores the inevitable bias which governs an historian's work, even in the choice of subjects to study. In France of the early nineteenth century, to escape these biases would have been an almost impossible task. Mellon does not give Guizot the credit of being sincerely curious about the history of his nation and of Europe which the man deserves. The Revolution, the Napoleonic Empire, and the Restoration created a thirst for understanding of the workings and causes of history, separate, to a considerable extent, from the historian's political views. Guizot's political attitudes were certainly important in bringing him to study the history of England and of the English Revolution, but to consider the numerous volumes which he produced on this subject as mere political propaganda is unfounded. Guizot was to a very great extent, as he called himself, a "man of yesterday," with an "affectionate respect for the great names and actions which have held such a conspicuous place in our destinies."It It is not the primary intention of this study to defend either Guizot's intentions or his historical work. There are many inadequacies in his works. For example, in his five volume History of England, there is no mention of John Locke and very little said of Thomas Hobbes: His intentions can never be adequately documented. The primary concern of this study is with the attitudes and values which emanate from his works, be they of an historical, literary, religious, or openly political nature.

13Johnson, Guizot, pp. 322-323.

${ }^{14}$ Guizot, Memoirs, I, 28. 
In 1830, Guizot was elected to the Chamber of Deputies. Two years later, he became Minister of Public Instruction. Except for the period from February to September of 1836, he remained in this post until 1837. His Ministry, Sainte-Beuve said, "ne mérite que des éloges." He was veritably in his niche. One can only regret, Sainte-Beuve pointedly remarks, that he did not remain Minister of Education rather than bowing to the temptation of politics. 15 In 1840, four years after his election to the Academie Francaise, Guizot became ambassador to London. In October, 1840, he became Foreign Minister. By the time of the February Revolution of 1848, Guizot had become president of the Council of Ministers. That Revolution ended his political career. He had enjoyed political power, but said that he did not lose it "without a sentiment of satisfaction, and almost of joy; like a laborious student who enters on his vacation, or a man who breathes freely when delivering himself from a heavy burden."16 While not overly bitter about his own fate, he found the condition of France, after 1848, extremely displeasing. Upon both "instinct and reflection," he said, he had an "antipathy to disorder," and disorder was the basis of the Second Republic.17

In July of 1849, Guizot returned to France from his London exile. He settled in Val Richer in Normandy. For the rest of his life he was occupied with literary, historical, and religious studies. Toward the end of his life, he was assisted by his daughter, Mme. Guizot de Witt, who completed the last few volumes of his History of France from his

15C.-A. Sainte-Beuve, Nouveaux Lundis (Paris: 1875), pp. 102-104. $16_{\text {Guizot, Memoirs, }}$ IV, 119-120.

17Guizot, Memoirs, II, 42. 
notes. He died on September 12, 1874, his final wish being to see a portrait of Coligny, the sixteenth century French Huguenot.

The central concept of Guizot's intellectual deliberations is civilization, whether of the past, the present, or the future. The first chapter of this study deals with his interpretation of the history of civilization in Europe, and the distinction which he made between pre-modern civilization, characterized by its simplicity, and modern civilization, the most obvious fact of which is its complexity. Modern civilization is more complex because of the diversity of elements and principles which strive for a foothold and, in their struggle, advance civilization. The most important of these elements are Christianity, monarchy, the Great Man, Providence, and the rise of the bourgeoisie. The second chapter deals with specific applications of the concept of the advancement of civilization through the competition of some of the elements in society. These examples are the Reformation, the English Revolution of the seventeenth century, and the French Revolution and its consequences for France in the nineteenth century. Along with this is an account of Guizot's attitudes toward revolution and reaction generally.

In the next chapter, Guizot's thoughts on liberty and order are portrayed, by means of a discussion of his attitudes about the condition of France, the American experiment, and the necessity for a gouvernement 1.ibre, which is also described. Examined in this section are Guizot's deliberations about law, liberty of the press, education, and man and his reason. A vital aspect of Guizot's thoughts about liberty and order treated in this chapter is his attitudes toward Democracy and the reformers of the social order. Finally Guizot's considerations about the 
role of the bourgeoisie in France, along with his thoughts on the relations of the classes in society, are described.

The final chapter deals with Guizot's notions about philosophy and religious thought, an area which is vital to an understanding of the man, though in this area he is less representative of nineteenth century French bourgeois intellectual currents. 


\section{CHAPTER II}

\section{CIVILIZATION}

In his lectures on The History of Civilization in Europe, Guizot begins with a disclaimer of any intention of approaching the problem of civilization with any sort of "scientific definition."18 It is much more meaningful, he explains, to investigate the "fact" of civilization "according to the common sense of mankind."19 Although a scientific definition would appear, at first glance, to be more clear and precise, it is really a dead end. It is much more profitable to be less definite in formulating a preliminary definition, he suggests, and offers his own:

Wherever the external condition of man extends itself, vivifies, ameliorates itself; wherever the internal nature of man displays itself with lustre, with grandeur; at these two signs, and often despite the profound imperfection of the social state, mankind with loud applause proclaims civilization. 20

It is obvious which of the two signs Guizot considered most important. If the external condition of man is improved, that is certainly to be appreciated, but civilization can-appear without it. It is the internal nature of man which is most essential. This is fundamental to Guizot's thought. The heart and mind of man must be reformed before the external

18François Pierre Guillaume Guizot, The History of Civilization in Europe, translated by Wm. Hazlitt (New York: A. L. Burt, N. D.), P. 9 .

${ }^{19}$ Guizot, Civilization in Europe, p. 9.

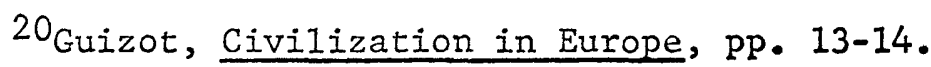


condition of man can be much improved. In his Mémoires Guizot answered his critics, who deplored what they felt to be his lack of concern with social and economic problems of society, by explaining that,

while sympathising deeply with the physical privations of the people, I have been more pre-eminently moved and engrossed by their moral wants; holding it for certain that, in proportion as the latter are ameliorated, they will struggle the more effectually against the former; and that to improve the condition of men we must first purify, strengthen and enlighten their minds. 21

It was in this light that Guizot saw early Christianity as an important civilizing force, even though it "in no degree addressed itself to the social state."22 Early Christianity concerned itself with the needs of the inner man. It changed his feelings and creeds and "regenerated the moral man, the intellectual man."23 Once the internal condition of man has been regenerated, social progress can and will take place, though there is usually a considerable time lag between progress in terms of the internal and external conditions of man.

Guizot's position is in agreement with the more fully developed argument of Hege1:

Only the Germanic peoples came /Hegel argued7, through Christianity, to realize that man as man is free and that Freedom of Spirit is the very essence of man's nature. This realization first arose in religion, in the innermost region of spirit; but to introduce it in the secular world was a further task which could only be solved and fulfilled by a long and severe effort of civilization. Thus slavery did not cease immediately with the acceptance of the Christian religion. Liberty did not suddenly predominate in states nor reason in govermments and constitutions. The application of the principle to secular. conditions, the thorough molding and interpenetration of the

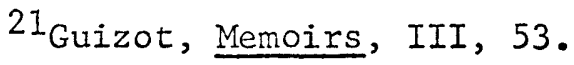

${ }^{22}$ Guizot, Civilization in Europe, p. 14.

23 Ibid., p. 14 .
} 
of the secular world by it, is precisely the long process of history. 24

This passage points to the difference between Guizot, whose observations were the thoughtful considerations of an intelligent man, and Hegel, the systematic philosopher. Guizot never set out to build an integrated philosophical system. In fact, he had an aversion to such endeavors, which he shared with the eighteenth century philosophes, although he would not have wished to be connected with them.

Guizot was convinced of the "universal" nature of civilization. To him, it seemed that there was a "general destiny of humanity" in which the sum total of civilization is transmitted throughout history. 25 Implicit within Guizot's thought is the notion of linear historical progress. It may be slow, and there will be considerable backsliding, but the ultimate direction is upwards. Progress Guizot defines as "the perfecting of civil life, the development of society, properly so called, [and] of the relations of men among themselves."26

Guizot was very much concerned with what he saw to be the main distinction between pre-modern and modern civilizations. The civilizations which preceded that of modern Europe "seem to have emanated from a single fact, a single idea." 27 The most striking aspect of pre-modern civilizations was the unity and simplicity which resulted from the

${ }^{24}$ G. W. F. Hegel, Reason in History--A General Introduction to the Philosophy of llistory, translated by Robert S. Hartman (Indianapolis and New York: The Bobbs-Merrill Company, Inc., 1953), p. 24.

${ }^{25}$ Guizot, Civilization in Europe, p. 6.

${ }^{26}$ Ibid., p. 11.

27 Ibid., p. 26. 
predominant single theme. For example, Guizot saw both Egypt and India as dominated by the theocratic principle. As a result, tyranny was the rule in both societies. In pre-modern societies or civilizations, the "excessively preponderating dominion" of a single system or principle of organization will usually result in tyranny or a pre-modern form of totalitarianism. This is antithetical to modern civilization, in which we are presented "with examples of all systems, of all experiments of social organization; pure or mixed monarchies, theocracies, republics, more or less aristocratic, have thus thrived simulcaneously, one beside the other."28 This "diversity of elements" which makes up modern European civilization has "given birth to the freedom which prevails in the present day." 29

Christianity was part of this plurality of principles and systems which led to the formation of modern European civilization. Guizot found the origins of Christianity to be "one of the strangest and most significant facts in history." Christianity is the "most universally human" religion, the most "dissociated from every consideration but that of the rights and well-being of the human race in its entirety." That this universal religion should have emanated from Judaism, "the most exclusive, most rigorously and obstinately national religion that ever

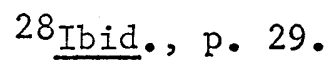

29 Ibid., pp. 30-31. This concept is not original with Guizot. Voltaire expressed it quite graphically in his Philosophical Letters when he observed that "If there were only one religion in England, there would be danger of tyranny; if there were two, they would cut each other's throats; but there are thirty, and they live happily together in peace." Voltaire, Philosophical Letters, translated by Emest Dilworth (Indianapolis, New York, and Kansas City: The Bobbs-Merrill Company, 1961), p. 26 . 
appeared in the world," he found to be one of the greatest marvels of history. 30 He was equally impressed by Christianity's ability to survive under the hostile Roman Empire and even to outlast it. The cause of this he saw in the gradual institutionalization of the faith into the Church. He saw the development of what came to be Catholicism as encompassing three phases. In the first, Christians were united by sentiment and indefinite religious convictions, in the absence of dogma, discipline or real institutions. In the second phase, due primarily to persecution, there emerged the Church organization and a codified doctrine which developed into Roman Catholicism. There was, at this point, still no clear separation of the Church from the faithful, nor the domination of the latter by the former. This characterized the third phase, in which the clergy had become distinct from the body of believers. Church organization was fully developed and was almost totally independent of the people for whom it had been created originally. 31 This last phase was extremely unfortunate, Guizot felt, but in the first two, and less so in the third phase, the contribution to civilization by Christianity had been considerable.

It was with the development of Christianity through the Church that "the separation of spiritual and temporal power" had its origins. This separation, which Guizot saw as "a great fact," is the "source of liberty of conscience," which is based upon the principle that "physical force has neither right nor influence over souls, over conviction, over

30François Guizot and Mme. Guizot de Witt, The History of France from the Earliest Times to 1848, translated by Robert Black ( 3 vols; New York: Worthington Co., N. D.), I, 89.

$31_{\text {Guizot, }}$ Civilization in Europe, p. 40. 
truth."32 This is the basis for his antagonism toward both state domination of the minds of men by force and Church domination of souls by the same method. Guidance is always necessary, but force is antithetical to truth.

Guizot's attitude toward the early Church was one of ambivalence. "The presence . - of a moral influence, the maintenance of a divine law, and the separation of the temporal and spiritual powers, are the three grand benefits which the Christian church in the fifth century conferred upon the European world."33 The worst aspect of the Church was its attempt to impose the theocratic principle upon Europe. Had the attempt succeeded, the progress of civilization would have been impeded, for the preponderance of any single principle, even theocracy, means that the civilization is pre-modern. The failure of the attempt allowed development to continue toward its modern condition, in which Christianity is only one force of many.

The evolution of Christianity was a difficult process, and one not immune to the influences of the mundane world:

Des intérêts matériels, des passions brutales, 1 'égoisme, I'orgueil, I'indifférence, l'emportement, les nécessités du moment, les combinaisons de la politique ont entravé, ralenti, souillé le developpement de l'idée chrétienne; mais elle n'a jamais abdique, jamais disparu. 34

The Church avoided losing the idée chrétienne by refusing to subjugate itself completely to the material world. Guizot sees this independence

$$
\begin{aligned}
& 32 \text { Ibid., p. } 45 . \\
& 33 \text { Ibid., p. } 46 .
\end{aligned}
$$

34François Guizot, Histoire Parlementaire de France, Complément

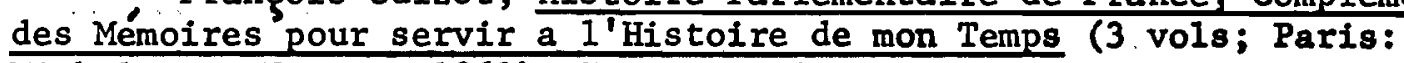
Michel Levy Freres, 1863), I, cxoorvili. 
as one of the most important aspects of Christianity, as opposed to most other religions. "The Christian Church is not like the pagan Antaeus, who renews his strength by touching the earth; it is on the contrary, by detaching itself from the world, and re-ascending towards heaven, that the Church in its hours of peril regains its vigour."35 By "detaching itself from the world," Guizot does not mean that the Church should abandon itself to a mystical isolation or a total withdrawal from the world. The Church has a vital role to play in civilization. It must concern itself with society at all times, but it must do so not out of material interests. It must be concerned with the souls of the men in society.

Guizot is adamant about the way in which the Church should approach society. "Is it not the asks7 . . by moral life, by internal movement, on the one hand, and by order and discipline on the other, that institutions take possession of society?"36 For him the answer is clearly yes. The Church must lead by example and must exemplify "order and discipline." This does not mean that the Church may force itself upon civilization. Religion must make itself acceptable to the people:

For religions to accomplish what they attempt, they must make themselves acceptable to liberty itself; it is needful that man should submit, but he must do so voluntarily and freely, and must preserve his liberty in the very heart of his submission. This is the double problem which religions are called upon to solve. 37

\author{
${ }^{35}$ Guizot, Memoirs, I, 262. \\ ${ }^{36}$ Guizot, Civilization in Europe, p. 100. \\ 37 Ibid., p. 138.
}


Men must always be guided, never driven. This is especially true in matters concerning the internal condition of man.

For the people to submit willingly, they must feel that they are influencing those who wish to guide them, and this, Guizot felt, was one of the main faults of Catholicism:

The characteristic fact $/ \bar{h}$ argues/, and, it must be so called, the radical vice of the relations of the church with the people, is the separation of the governing and the governed, the noninfluence of the governed in their government, the independence of the Christian clergy with regard to the faithful. 38

The role which Christianity plays in the history of civilization is not limited merely to the individuals of a given society. Modern European civilization is made up of a "community" of societies which "know, comprehend, visit, and imitate each other, with mutual and incessant modification. In spite of all the differences and conflicts within European society, "a deep and dominant unity reigns in its moral life as in its destinies. Let us call it Christianity. In this is comprised our original character and our glory." 39 The society of European nations had developed with and because of Christianity, "the most extensive as well as the most beautiful example of association amongst different states and peoples." Although the relations of the European states are "morally superior to all other historical associations," they have still "bordered on barbarism." 40 This statement should not be interpreted as pessimistic. Society is very young, as can be seen by comparing the actual condition of the world with what one would prefer it to be more like.

$$
\begin{aligned}
& 38_{\text {Ibid., p. } 124 .} \\
& { }^{39_{\text {Guizot, Memoirs, }}}, \text { IV, } 4 . \\
& { }^{40} \text { Ibid.., II, 236. }
\end{aligned}
$$


It has only been in recent times that the human mind along with human society have achieved some semblance of peace and hamony. Progress is being made, if slowly. 41 But Christianity is only one of the principles upon which progress in and toward a modern pluralist society is based, even if it is a very important one.

Another important principle in the development of civilization is the monarchy:

It is evident that royalty has played a prodigious part in the history of European civilization; a single glance at facts suffices to convince one of it; we see the development of royalty marching with the same step, so to speak, at least for a long period, as that of society itself; [their] progress is mutual. 42

The progress of monarchy cannot be traced, Guizot contended, solely to force. "Force plays a great part and an incessant one in human affairs; but it is not their principle, their primum mobile." More Important than force, there is a "moral cause which decides the totality of things." Guizot compares the role of force in history with the role the body plays in the life of man. The body is of great importance, but it is not the "principle of life." Life circulates within the confines of the structure, but it does not "emanate from it." The same is true of force in. civilization. Whatever part it plays, it does not govern history. It is "ideas and moral influences, which conceal themselves under the accidents of force and regulate the course of the society. "43 It is the moral influence and the truth within the principle of monarchy to which its rise must be traced.

${ }^{41}$ Guizot, Civilization in Europe, pp. 21-22.

42 Ibid., p. 195.

43 Ibid., pp. 196-197. 
The role of the monarchy differs from country to country in Europe. As a positive force for good, Guizot saw it as more important in France than in England. France had "prospered under the influence of royalty seconding the ascending movement of the middle classes." In England, it was the landed aristocracy which took charge of "the liberties of the people. "44 In England, the monarchy had been a much more negative force that, as a result of its pretensions, had stimulated the aristocracy to take a leading role in the fight for liberty. For example, Guizot argued that the reign of John Lackland,

the most cowardly and treacherous of the sovereigns who have sat on the throne of England, is one of the most important epochs in history, for from that time dates the active part played by the nation in its own affairs--the time of the Magna Charta, the germ and foundation of all English liberty. 45

Guizot traces the Parliaments as defenders of liberty back to Edward I. He mistakenly saw them as the people's response to the power of the monarch rather than, as they really were in this period, a royal institution for better administration and collection of revenue. By the death of Edward I, he insists, "the charters had been so firmly established in England, that no monarch dreamed of disturbing them again, until the unhappy days of Charles I." The frequent meetings of the Parliament were assurance for the "liberties of the nation . . . The constitution of England was founded." 46 By the time of Henry IV (13991413), the "House of Commons, espectally, had seen its privileges

${ }^{44}$ Guizot, Memoirs, I, 307.

45 François Guizot, A Popular History of England, From the Earliest Times to the Accession of Victoria, translated by M. M. Ripley (5 vols; Boston: C. F. Jewett Publishing Co., 1876), I, 203.

${ }^{46}$ Ibid., I, 271. 
confirmed . . and its influence had been constantly growing." The liberties of England, "formerly conquered by the barons at the price of much bloodshed," were now profiting from the weakness of the sovereigns. 47 They were to be attacked once again under the Stuarts, but then "the religious reform was to raise them to their highest pitch." 48

The English monarchs were not the only ones to be "led away by the dangerous intoxication of absolute power." The French kings were also guilty, if perhaps slightly less so. An example of this was given by Louis XIV, when he "thought himself powerful enough to impose his will on the consciences of his subjects, and [was7 convinced that no one would resist him." Believing that "preliminary persecutions" had paved the way, he revoked the Edict of Nantes on October 22, 1685.49 Force was always repugnant to Guizot, but because he was a Protestant, this particular act seemed especially distasteful to him.

Despite such incidents, the positive importance of the monarchical principle for France could not be denied. As suggested above, one of the reasons he saw the monarchy in such a favorable light was that the middle classes had been helped along by the monarchy. This was the result of the French aristocracy's mistake of regarding "politics" as beneath them. At times they would serve the king, but most of the time they spent in opposition. As a result,

1a royauté entravée, harcelée, depouillée par la haute noblesse, a recherché, contra elle, l'appui de la bourgeoisle et du peuple; la bourgeoisie et le peuple, pour s'affranchir du joug arrogant de

${ }^{47}$ Guizot, Civilization in Europe, p. 378.

48 Ibid.

${ }^{49}$ Guizot, England, III, 323. 
la noblesse, ont recherché, a tout prix, l'appui de la royauté. L'aristocratie n'a su prendre sa place ni dans le gouvernement de l'État, ni dans la cause des libertés publiques; la démocratie n'a grandi que dans 1'alliance et au service du pouvoir absolu. 50

A complementary principle, to the monarchy is the concept of the Great Man. Great men do "great things which would not get done without them; they set their mark plainly upon history."51 To a certain extent they are prophets, but their foresight is usually limited to the present, an idea which sounds more paradoxical than Guizot feels it really is. Great men are, like Guizot, not system builders. They are intuitive and at the same time realistic creatures, working within the bounds of vague but rea1 limits:

The great men of action never construct their plan of action beforehand or in one piece. Their genius lies in their instinct and their ambition. From day to day, in each circumstance as it occurs, they see facts such as they really are. They discern the path which these facts indicate, and the chances which that path opens to them. They enter it resolutely, and advance along it, still guided by the same light, as far as space opens before them. 52

Their clarity of vision extends only to the needs of their own times, and then it is often clouded. Great men "are far from doing all they meditate, and they know not all they do. They are at once and the same time instruments and free agents in a general design which is infinitely above their ken." If these men realize their precarious position and accept their role for what it is, they will accomplish much. If they refuse to do so, "they will become the dupes and frequently the victims

50 Guizot, Histoire Parlementaire, I, xi.

$51_{\text {Guizot, }}$ History of France, I, 200.

52François Guizot, History of the English Revolution of 1640 , From the Accession of Charles I to His Death, translated by Wm. Hazlitt (London: Be11 and Da11y, 1870), p. 27. 
of a blind pride which events in the long run always end by exposing and punishing. ${ }^{153}$ Great men are limited by ethical considerations as well. They are working toward the realization of God's plan, and to do so they must stay within the bounds of morality. For Guizot, the ends do not justify the means. By placing this restriction upon the great men of history, he parts company with philosophers such as Hegel, who maintain that world-historical men "stand outside of morality. The litany of the private virtues of modesty, humility, love, and charity must not be raised against them." 54

The characteristics and faults of the great figures in history are found in a diverse number of individuals. They range from Joan of Arc and Charlemagne to Cromwell and Napoleon to George Washington and William Pitt.

For example, he saw Joan of Arc as the "weakest instrument which it has ever pleased God to employ for the accomplishment of His designs." 55 He does not question her visions or the authenticity of what she claimed to be. Although he was a Protestant, he would have been pleased had he known that she would be canonized.

${ }^{53}$ Guizot, History of France, I, 200-201. Guizot's great men are considerably less potent than Hegel's, whose great men "see the very truth of their age and their world, the next genus, so to speak, which is already formed in the womb of time. It is theirs to know this new universal, the necessary next step of their world, to make it their own aim and put all their energy into it. The world-historical persons, the heroes of their age, must therefore be recognized as its seers." Hegel, Reason in History, p. 40.

${ }^{54}$ Hege1, Reason in History, p. 83.

55 Guizot, England, II, 22. 
Charlemagne is another of Guizot's "heroes," and one who was impressive, at least in part, because of the "striking variety of his ambition, his faculties, and his deeds." He "aspired to and attained to every sort of greatness," be it of a military, political, or intellectual nature. This is particularly remarkable, Guizot felt, since his achievements came "in a time of general and monotonous barbarism when, save in the Church, the minds of men were du11 and barren."56 Much of Guizot's sympathy for Charlemagne stems from the fact that no matter from what "point of view you consider the reign of Charlemagne, you will always find in it the same character, namely, warfare against the barbarous state, rand for 7 the spirit of civilization."57 Charlemagne was unable to fully accomplish his aim of bringing civilization out of barbarism, as all such attempts from the fifth to the ninth century had failed, but his aspirations were noble and worthy of praise.

His efforts in another direction, that of strengthening the principle of monarchy in his time, were more fruitful. Once again, however, Guizot emphasizes the limitations under which such men labor:

Whoever is astonished either at this triumph of absolute monarchy through the personal movement of Charlemagne, or at the speedy fall of the fabric on the disappearance of the moving spirit, understands neither what can be done by a great man,

${ }^{56}$ Guizot, History of France, I, 167.

57Guizot, Civilization in Europe, p. 71. In contrast with Guizot's hostility to the barbarous, Michelet gloried in it: "Often, in these days, the rise and progress of the people are compared to the invasion of the Barbarians. The expression pleases me; I accept 1t. Barbariansl Yes, that is to say, full of new, living, regenerating sap. Barbarians, that is, travellers marching toward the Rome of the future." This typifies the contrasting characters of the contemporaries. In Varleties of History, edited by Stern, p. 116 . 
when, without him, society sees itself given over to deadly peril, nor how unsubstantial and frail is absolute power when the great man is no longer by, or when society has no longer need of him. 58

As to Charlemagne's imperialistic endeavors, Guizot felt that he was lucky in that they "perished with him," while his more "salutary achievement, the territorial security of Christianity," has lasted to the present, "to the great honor as well as great profit of European civilization." 59

A figure with whom Guizot is, for the most part, much less in sympathy is Cromwe11. In his general History of England, Guizot treats Cromwe11 rather favorably, stating that,

In the midst of the disorder and violence which he could not or would not repress, Cromwell always had the credit of understanding and respecting liberty of conscience . . . Few despots have understood like Cromwell how to restrain themselves within the limits of practical necessity, while leaving to the human mind a vast and free field of action. 60

In his more specific, and far more scholarly, work on the English Revolution, he is much more critical of the Lord Protector. God, he says, did not wish to allow the same man who "had laid the king's head low, and trampled under foot the liberties of the country," to re-establish the monarchy and reinstate the "legitimate parliament." Cromwell had been given the privilege of bringing the Revolution to the dictatorship, but he was not allowed to "transform the dictatorship into a rule of right and of liberty."61 It was Cromwel1's own "unlawful deeds" which

$$
\begin{aligned}
& { }^{58} \text { Guizot, History of France, I, 186-187. } \\
& { }^{59} \text { Ibid., I, } 201 . \\
& { }^{60} \text { Guizot, England, III, } 173 . \\
& 61_{\text {Guizot, English Revolution, }} .41 .
\end{aligned}
$$


"neither his powerful genius nor his obstinate wi11" could overcome.62 Herein is furnished an example of the moral limits which a great man must work within or fail.

Guizot was an uncritical admirer of George Washington, who led the American Revolution in a way which Guizot found much more acceptable than the methods employed by CromwelI. In 1839, Guizot contracted to translate and edit Washington's papers and correspondence. At that time he "beheld Washington possessed from his first movements by a judicious and virtuous apprehension,--the dread of popular and anarchical violence."163 He came to see Washington as the "model for democratic chiefs," who struggled against the "exactions" of Democracy, which Guizot so passionately abhorred. The American realized, Guizot continued, that "it is no more possible to govern from below in a republic than in a monarchy."64 The people must be led from above if liberty is to be substituted for either tyranny or anarchy. Washington believed in the correctness of his position and had the courage to act, "without fear of responsibility."65 Guizot was also convinced of the correctness of Washington's convictions and was pleased at what he felt to be his success :

There is a spectacle as beautiful and not less salutary than that of a virtuous man struggling against adversity: it is the

${ }^{62}$ Guizot, England, III, 194-195.

${ }^{63}$ Guizot, Memoirs, IV, 316.

64François Guizot, Democracy in France (London: John Murray, 1849), pp. 13-14.

65 Guizot, England, IV, 237. 
spectacle of a virtuous man at the head of a good cause achieving a triumph. God reserved this happiness for George Washing$\operatorname{ton} .66$

Even when Guizot disliked a great man and what he attempted to do outside of the limits of morality or practical necessity, he could appreciate his positive achievements. Such a case is that of Napoleon Bonaparte, who was, of al1 the men of his rank, "by far the most necessary for his times." No one but Napoleon "could have so quickly and effectually substituted order in place of anarchy." 67 The other great achievement of Napoleon was to make France's "national independence firmly established."68 Even so, Bonaparte was flawed; his great fault was that he was a despot. "For me /Guizot says]7, under the Empire, there was too much of the arrogance of power, too much contempt of right, too much revolution, and too little liberty."69 Napoleon was a clear example of a man who was necessary at a particular moment but who was unfitted to carry on in a leading role after that moment had passed, and the "sane and permanent state of society" had returned. Napoleon saw the needs of the moment quite clearly and accurately, but "no one was so chimerical as to the future." 70 In this respect he is fairly typical of Guizot's great men. Because of his faulty vision, he lost the support of the nation and was driven from Europe. His return for the Hundred Days failed not because he had lost any of his milltary

$$
\begin{aligned}
& { }^{66} \text { Ibid., IV, } 236 . \\
& 67_{\text {Guizot, Memoirs, I, } 5 .} \\
& 68_{\text {Guizot, Democracy, }} \text {, } 12 . \\
& 69_{\text {Guizot, Memoirs, I, } 5 .} \\
& 70_{\text {Ibid., I, } 5 .}
\end{aligned}
$$


genius, but because he could not gain the support of "general opinion," without which any would-be leader has no chance. He attempted a "mischievous work, a work inspired only by his own passions and personal wants, rejected by the morality and good sense, as well as by the true interests of France."71 Any time a great man leaves the interests and needs of his society and enters into a path dictated by self-pride and self-interest alone, his society will desert him and he will fall.

A final example of the great man as Guizot saw him is offered by William Pitt, of whon Guizot says, "It was to his honor that he always chose that difficult path--the only one worthy of men called by God to govern their fellow-men--equally removed from both extremes, and resisted the extravagances of liberty as well as the arbitrary leaning towards despotism. 172

As the result of studying the lives of so many "great men," Guizot came to the conclusion that one could not generalize about the effects of power on men. It had different effects on different men. It "hardens and corrupts some [such as Napoleon], while it humanizes and exalts others [like William Pitt and Washington]."73

The principle of the Great Man cannot be divorced from the equally important concept of Providence in history. For it is Providence which imposes the tasks that great men perform. Providence is not always too particular whom it chooses to carry out a task:

When honest men fail to understand or execute the designs of Providence, dishonesty undertakes the task. Under the pressure

$$
\begin{aligned}
& 71_{\text {Ibid. }}, \text { I, 65-66. } \\
& 72_{\text {Guizot, England, IV, } 317 .} \\
& 73_{\text {Ibid., I, } 76 .}
\end{aligned}
$$


of circumstances, and in the midst of general weakness, corrupt, sagacious and daring spirits are ever at hand, who perceive at once what may happen, or what may be attempted, and make themselves the instrument of a triumph to which they have no natural claim, but of which they assume the credit, to appropriate the fruits. 75

When Guizot wrote these lines, he was thinking of Fouche, and his role during the Hundred Days and the second restoration of Louis XVIII. He disliked Fouché, but did not deny the importance of his role in that period. Fouché was not immune to criticism for his moral transgressions, as Hegel had argued, merely because he was important in the plan of Providence.

The plan of Providence was generally seen by Guizot to be intelligible by man--or at least by some men. Nations must discern this plan and learn to follow, "alternately by submission and by action, the counsels which God has given them in the events of their life."76 It was clear to Guizot that "European civilization has entered, if we may so speak, into the eternal truth, into the plan of Providence; it progresses according to the intentions of God. This is the rational account of its superiority."77 In a letter to his second wife, Eliza, he expressed his firm faith in the workings of Providence:

Je les trouve manifestes dans 1 'histoire du monde, d'une façon aussi certaine que dans la marche des astres; je vois Dieudans les lois qui règlent le progrès du genre humain, aussi present, aussi évident, bien plus évident, selon moi, que dans celles qui président au. lever et au coucher du soleil . . . C'est dans le spectacle de l'humanité, de sa vie et de sa destinée générale

$$
\begin{aligned}
& 74 \text { Guizot, English Revolution, p. } 53 . \\
& 75_{\text {Guizot, Memoirs, I, } 94 .} \\
& 76_{\text {Guizot, English Revolution, p. } 68 .} \\
& 77_{\text {Guizot, Civilization in Europe, p. } 32}
\end{aligned}
$$


que $j^{\prime} a i$ puisse une entière certitude, une confiance infinie dans la sagesse et dans la bonté, et l'action permanente de la Providence. 78

The importance of the Great Man, the monarch and Providence have been discussed, but of what importance is the ordinary man to the process of civilization? His role turns out to be rather more important than one might expect. "After a11, whatever external events may be, it is man himself who makes the world; it is in proportion to the ideas, sentiments and dispositions, moral and intellectua1, of man, that the world becomes regulated and progressive." He reminds us that "it is upon the internal condition of man that the visible condition of soclety depends."79 We have thus come full circle. As soon as man's internal condition is improved, he is stimulated into action. He "feels himself impelled, compelled by his instinct, by an inward voice, to extend to others the change, the amelioration, which has been accomplished in his own person." 80

Along with the concern for the role of men individually, there is the question of the importance of groups or classes of men in the history of civilization. The role of the landed aristocracy in England has

78 de Witt, Dans sa famille, pp. 117-118.

${ }^{79}$ Guizot, Civilization in Europe, p. 64.

80 Ibid., p. 18. On this point Hegel's argument is again more complete, but in basic agreement with Guizot's: "Purposes, principles, and the like are at first in our thoughts, our inner intention. They are not yet in reality. . . A second element must be added for 「them 7 to become reality, namely, activity, actualization. The principle of this is the will, man's activity in general. The activity which puts them in operation .. is the need, the instinct, the inclination, and passion of man. When $I$ have an idea $I$ am greatly interested in transforming it into action, Into actualization." Reason in History, pp. 27-28. 
already been briefly mentioned. In France, where the aristocracy shunned politics, the monarchy turned to the emerging bourgeoisie for help and aided it in its rise. Guizot, a good bourgeois himself, sees the role of the middle classes as very important in French history, particularly. When one considers the history of France, "in its entirety and under a11 its phases, the third estate has been the most active and determining element." It first allied itself with the monarchy against the feudalistic aristocracy. Once that battle had been won, it turned upon the absolute monarchy which it had helped to create and began "the task of changing pure monarchy into constitutional monarchy." This phenomenon, Guizot reports rather proudly, is unique to France. Nowhere else in the world

is there any appearance of a class which, starting from the very lowest, from being feeble, despised, and almost imperceptible at its origin, rises by perpetual motion and by labor without respite, strengthens itself from period to period, acquires in succession whatever it lacked, wealth, enlightenment, influence, changes the face of society and the nature of government, and arrives at last at such a pitch of predominance that it may be said to be absolutely the country. 81

The history of the bourgeoisie is complex. Elements of it will be traced in following chapters in which Guizot's views on the Reformation and the English and French Revolutions are discussed. At this point, a few brief comments will suffice. Guizot saw the antecedents of the middle classes in the communes of the medieval world. They "descend, principally at least, from the burghers who obscurely though courageously revolted in the twelfth century, with the sole end of escaping in some corner of the land from the obscure tyranny of the 1ords. 82 This "local

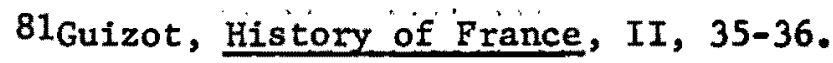
${ }^{82}$ Guizot, Civilization in Europe, p. 153. 
enfranchisement of the burghers" led to the "formation of a great social class, the bourgeoisie." In its "bosom" can be seen the "successive rise of new professions, new moral positions, and a new intellectual state."83 The classes which make up societies have "always struggled." They have always "detested each other." The

utter diversity of situation, of interests, and of manners, produced between them a profound moral hostility: and yet they have progressively approached nearer, come to an understanding, and assimilated; every European nation has seen the birth and development in its bosom of a certain universal spirit, a certain community of interests, ideas, and sentiments, which have triumphed over diversity and war. 84

Thus is made clear Guizot's interpretation of the significance and the mission of the bourgeoisie. Its importance is moral rather than economic. The people of the middle classes are materially better off because they are interna1ly superior. Their mission is to raise the internal nature of the rest of society to their level, to create a "certain universal spirit, a certain community" where there had been disunity and strife. 85

The most important principles and systems which have exerted great force in the history of civilization so far have been viewed as more or less isolated phenomena. It is their interaction, be it in terms of competition or cooperation, which has differentiated modem civilization, and more particularly the nation, from their pre-modern counterparts. This is shown very clearly in Guizot's definition of the nation. It is not, he says, merely a "vast aggregate of men, consisting of so many

$$
\begin{aligned}
& { }^{83} \text { Ibid., pp. 163-164. } \\
& { }^{84} \text { Ibid., p. } 165 . \\
& { }^{85} \text { Ibid., p. } 165 .
\end{aligned}
$$


thousands or millions, occupying a certain extent of ground, and concentrated in, and represented by, a unit, called king or assembly." A nation is a "great organic body," which is formed by a combination of "certain social elements which assume the shape and constitution naturally impressed upon them by the primitive laws of God and the free acts of man." 186

For Guizot, each attempt to impose a pre-modern unity upon civilization is a contribution to the development of modern civilization-as long as the attempt fails. For example, the Roman Empire's "bequeath" to history consisted of the municipal system of government and "a general and uniform civil legislation, the idea of absolute power, of a sacred majesty, of the emperor, the principle of order and subjection."87 Because Rome ultimately failed to establish the predominance of its principle, it made a contribution. Had it succeeded, civilization would have remained pre-modern. Thus, Rome should be criticized for making the attempt, but had they not made it, an important element of modern civilization would be missing.

The fall of Rome led to barbarism as the characterizing feature of civilization. Barbarism for Guizot meant "the chaos of all elements, the infancy of all systems, an universal turmoil, in which even strife was not permanent or systematic."88 States rose and fell, there "were no boundaries, no governments, no distinct people; but a general confusion of situations, principles, facts, races and languages; such was

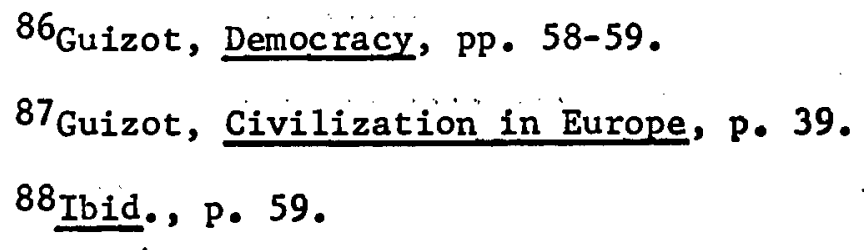


barbarous Europe."89 He found this condition unacceptable in itself, but the phase was necessary as the embryo of modem European civilization. Out of this chaos of forces was to develop the great "fact" of civilization. In barbarism, the competing principles had no strong hold on the people. The basic ingredient of modernity, the plurality of principles and systems, was present, but it took time for them to take root and flourish.

One of the first principles to gain a permanent foothold was Christianity. Guizot maintains that it was to Christianity that "the middle ages owed knighthood, that institution which, in the midst of anarchy and barbarism, gave a poetical and moral beauty to the period." Thus, when Christianity had been firmly established, but not as the only principle of civilization, it gave birth to another principle. Then the two combined to produce "the two great and glorious events of those times, the Norman conquest of England and the Crusades."90 These two events, and especially the Crusades, had a tremendous impact on civilization's development:

When we consider the state of minds in general, at the end of the crusades, and particularly in ecclesiastical matters, it is impossible not to be struck by one singular fact: religous ideas experienced no change; they had not been replaced by contrary or even different opinions. Yet minds were infinitely more free; religious creeds were no longer the only sphere in which it was brought into play; without abandoning thern, it began to separate itself from them, and carry itself elsewhere. Thus, at the end of the thirteenth century, the moral cause which had determined the crusades, which was at least its most energetic principle, had vanished; the moral state of Europe was profoundly modified. 91

$$
\begin{aligned}
& { }^{89} \text { Ibid., p. } 61 . \\
& 90 \text { Guizot, History of France, I, } 264 . \\
& 91_{\text {Guizot, }} \text { Civilization in Europe, pp. 189-190. }
\end{aligned}
$$


As a result of the Crusades, other elements of the developing civilization were strengthened and began to play a more important role. The feudal aristocracy, the clergy, and the monarchy "by turns possessed EEurope7, successively presided over its destiny and its progress."92 It was as a result of their "coexistence and their struggles" that Europe received its "liberty, prosperity, enlightenment; in a word, . . . the development of its civilization."193 It must be emphasized that progress resulted from struggles, which were in themselves bad. For example, his description of the thirteenth century crusade against the Albigensians portrays it as

the most striking application of two principles equally false and fatal, which did more than as much evil to the Catholics as to the heretics and to the papacy as to freedom; and they are, the right of the spiritual power to claim for the coersion of souls the material force of the temporal powers, and its right to strip temporal sovereigns, in case they set at nought its injunctions, of their title to the obedience of their people; in other words, denial of religious liberty to conscience and of political independence to states .94

When pre-modern civilization becomes modern, these struggles decrease in frequency and intensity--or at least they should, Guizot feels. As we sha11 see in subsequent chapters, by the nineteenth century such strife should cease. By the nineteenth century, the framework for combining liberty and order had been established, though it was not completely secure. Progress must be slow and orderly in the future, or the achievement of modern civilization would be jeapardized.

${ }^{92}$ Guizot, English Revolution, p. xiv.

93 Ibid., p. xiv.

${ }^{94}$ Guizot, History of France, I, 406. 
In the fourteenth century, the states-general had "won for France" the "principle of the nation's right to intervene in their own affairs, and to set their government straight when it had gone wrong or was incapable of performing that duty itself."195 The eighteenth century French Revolution completely reaffirmed that right. In the nineteenth century, Guizot argued, the danger was that the right would be abused. The right to liberty had been assured, but the practice of liberty had not.

95 Ibid., II, 129. 
CHAPTER III

REFORMATION, REVOLUTION, AND REACTION

\begin{abstract}
When we compare attentively the history and social development of France and England, we find it difficult to decide by which we ought to be most impressed,--the differences or the resemblances. Never have two countries, with origin and position so totally distinct, been more deeply associated in their respective destinies, or exercised upon each other, by the alternate relations of peace and war, such continued influence. 96
\end{abstract}

Interest in and admiration for English history and institutions was a basic part of Guizot's personality. This phenomenon was by no means rare for Frenchmen of the eighteenth and nineteenth centuries. Stanley Mellon has argued that when Guizot began to study the history of England, he "did so to demonstrate what every Restoration Liberal was prepared to believe on faith--that the eighteenth century French Revolution was only the latter-day version of the seventeenth-century English Revolution."97 This statement is not really accurate, for Guizot saw some very important differences between the two revolutions, many of which stemmed from the different courses that the Reformation took in the two countries. Therefore, before turning to the revolutions, it is necessary to take a look at Guizot's treatment of the Reformation in France and England.

The sixteenth century in Europe was a period which presented "that character of duplicity and falsehood which necessarily results from the absence of publicity and control, but which renders history difficult to

96Guizot, Memoirs, I, 305.

97 Melion, Political History, p. 16. 
understand and more difficult to relate."98 Despite the acknowledgment of these difficulties, Guizot made the attempt to both understand and discuss the period, the "essential character" of which he saw to be "impulse of thought and the abolition of absolute power in the spiritual order." 99

Guizot saw British Christians as always having been somewhat different from the other sects. They "were not heretics, but, with the independence which always characterized their race, they differed from Rome and from the Eastern Church upon various points," which were not very important in themselves, but which "had often created divisions in Christendom."100 The causes of the Reformation could be traced, in England and in France, back to the middle ages. The pre-eminence of the "great race of priests" in that period was "the source of much good and evil alike, until the period when the magnitude of their pretensions and the abuse of their power brought about the great revolt."101 with Wycliffe, who was born in 1324, we have the "first of the Reformers, or rather their precursor," whose doctrines were more important outside of England than in it. The "first germs of the Reformation in Bohemia" were the results of his works. The "most important of his ideas was the appeal to the private judgment of the faithful upon the very text of the Holy Scriptures."102

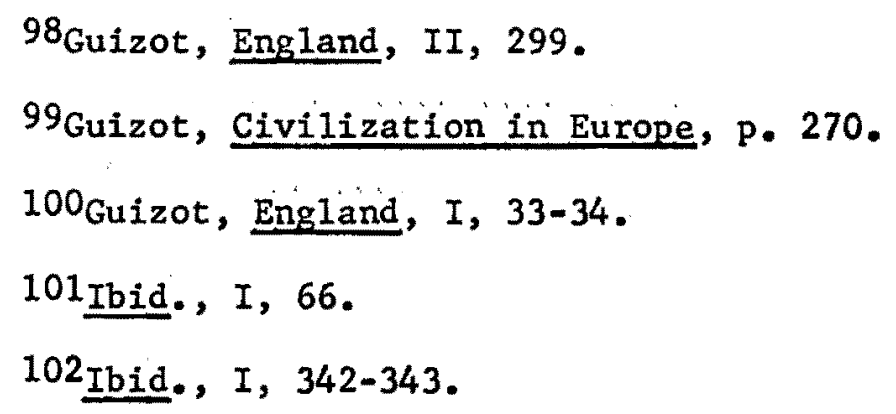


Guizot makes it clear that when the movement gathered speed, it did so primarily out of religious, not political sentiments:

It was in the name of Faith, and of religious liberty, that, in the 16th century, commenced the movement which, from that epoch, suspended at times, but ever renewed, has been agitating and exciting the world. The tempest rose first in the human soul: it struck the Church before it reached the State. 103

Because of the political implications of the English Reformation, and its inauguration by Henry VIII, Guizot takes pains to dissociate the monarch from the religious significance of the act. It is "to God, through the hands of Henry VIII, that England owes this great step in her victory; she has no obligation to be grateful for it to the despotic and corrupt monarch," who severed relations with Rome merely "in order to repudiate his wife and to dispose at his pleasure of the ecclesiastical benefices."104 Henry's motives were wrong, but the act itself was the right one for England. By separating from Rome, even though for political and private reasons, Henry VIII "had implanted in the English soil the germ of that religious liberty which was destined never to perish."105

After "the new spirit" of the Reformation had been instilled in many of the English people, it spread to politics. The "day of the Puritans was about to dawn; the obstinate resistance of weakness under a powerful oppression was already preparing. Protestant England had sprung into existence."106 The Refomation addressed itself first to the inward

${ }^{103}$ Guizot, English Revolution, p. 1.

${ }^{104}$ Guizot, England, II, 168-169.

105 Ibid., II, 215.

${ }^{106}$ Ibid., II, 216. 
nature of man and reformed it. Once the inward man had been regenerated, external refom could take place. The internal regeneration was not complete under Henry VIII. It continued during the brief reigns of Edward VI and Mary. Under Edward, the "immense progress" of three "social forces - . regard for public order, the idea of the royal legitimacy, and the spirit of the Reformation," foiled the "ambitious designs and plots of the great nobles."107 During the five year reign of Mary, there were 288 religious executions and numerous imprisonments. "Most of the victims belonged to the middle class and to the people; it was here that was manifested the most faithful attachment to the doctrines of the Reformation." 108 The middle class took the lead, as Guizot felt it always did, in improving both the internal and external conditions of man.

They continued to take the lead under Elizabeth, when all "the weight of her authority did not prevent the most fervent Protestants of her kingdom from being convinced, especially among the middle classes, that the Reformation had been too quickly checked In England."109 By the end of her reign, the House of Commons refused to grant the subsidies she called for until something was done about the commercial monopolies she had granted. "The ministers endeavored to defend the prerogative, but Parliament held firm; the Puritan spirit had been constantly gaining ground during recent years, and the queen was compelled to yield."110 The Puritan spirit had made the English nation very tired of the absolute

$$
\begin{aligned}
& { }^{107} \text { Ibid., II, } 231-232 . \\
& { }^{108} \text { Ibid., II, } 260 . \\
& { }^{109} \text { Ibid., II, } 307 . \\
& 110_{\text {Ibid., II, } 354 .}
\end{aligned}
$$


power wielded by the Tudors. "With all their exaggerations, their narrow minds, the severity of their principles, the Puritans were to become for their country the salt of the earth. They were to save it successively from despotism and from corruption, from the ruin both of liberty and of morals."111 His praise of the Puritans, which he often seems to equate with English Protestantism, is qualified, if sincere. He is distressed by the fact that "instead of recognizing and respecting their mutual rights, protestants and catholics only thought of persecuting and ens laving one another."112

The Reformation in France took a different course from its English or German counterpart. In the sixteenth century, unlike Germany, France was a unified nation under a strong monarchy. There were no powerful and independent states within France, "which could offer to the different creeds a secure asylum and could form, one with another, coalitions capable of resisting" the monarch. Unlike Henry VIII in England, the French monarch, Francis $I$, was not "audacious enough and powerful enough to gratify his personal passions" at the cost of a struggle against "the spiritual head of Christendom."113 Thus, the Reformation in France did not have the political boost it received in the other two countries, to make "its first steps more easy and more secure. It was in the cause of religious creeds alone and by means of moral force alone that she the French Reformation7 had to maintain the struggles in which she engaged."114

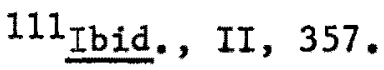

$112_{\text {Guizot, English Revolution, p. } 61 .}$

113 Guizot, History of France, III, 143.

114 Modern scholars disagree. See F.C. Palm's studies of the period. 
He does not fail to criticize the Protestants, admitting that wherever they happened "to be the stronger and where they had either vengeance to satisfy or measures of security to take, the Protestants were not more patient or more humane than the Catholics."115 Most of the time the Catholics were the stronger, however, and they therefore committed most of the atrocities. The worst of these was the St. Bartholemew's Day Massacre, of which Guizot's treatment is very limited and guarded:

History must show no pity /he explains $/$ for the vices and crimes of men, whether princes or people; and it is her duty as well as her right to depict them so truthfully that men's souls and imaginations may be sufficiently impressed by them to conceive disgust and horror at them; but it is not by dwelling upon them and by describing them minutely, as if she had to exhibit a gallery of monsters and madmen, that history can lead men's minds to sound judgments and salutary impressions: it is necessary to have moral sense and good sense always in view and set high above great social troubles. . . We take no pleasure and we see no use in setting forth in detall the works of evil: we should be inclined to fear that, by familiarity with such a spectacle, men would lose the perception of good and cease to put hope in its legitimate and ultimate superiority. 116

When one writes history, there is always the danger of brutalizing the readers. No attempt should be made to paint the whole picture just as it was. Guizot was not Ranke.

By the end of the religious wars and the accession of Henry IV, it was clear that Protestantism would never be the dominant religion in France. Guizot felt that it was impossible to accurately measure all of the different factors leading up to Henry's abjuration, but he was convinced that "patriotism was uppermost in Henry's soul, and that the idea of his duty as king towards France, a prey to all the evils of ${ }^{115}$ Guizot, History of France, III, 247. ${ }^{116}$ Ibid.., III, 300. 
civil and foreign war, was the determining motive in his resolution."117 Not to abjure would be to lead France into further turmoil, and to ignore his duty to the nation. His abjuration led to the Edict of Nantes and the Peace of Vervins with Philip II of Spain. These two acts, Guizot argues, were the "most timely and most beautiful acts in the world for France." 118

The political fruits of the Reformation in England were much more immediately apparent than in France. Instead of an Edict of Nantes, which placed the Protestants under the protection of the state, the Protestants in England came to dominate the state. In the process, they created a revolution.

In July of 1832 , Guizot wrote to the Duc de Broglie about his study of the English Revolution:

$J^{\prime} y$ prendais un plaisir infini, non seulement dans une vue politique, mais aussi et même surtout parce que je ne connais aucune grande histoire où éclate si evidemment, si glorieusement le triomphe de la sagesse divine au milieu et au travers de la folie humaine. C'est toujours dans quelque contemplation de ce genre que je me repose et me refraichs avec délices des fatigues et des mécomptes de la vie. 119

Guizot believed that the English Revolution was justifiable insofar as

$$
\begin{aligned}
& 117_{\text {Ibid. }} \text { III, } 393 . \\
& 118_{\text {Ibid. }}, \text { III, } 444 .
\end{aligned}
$$

${ }^{119}$ Lettres de M. Guizot à sa famille et à ses amis, edited by Mme. Guizot de Witt (Paris: 1884), p. 111. G. P. Gooch agrees with Stanley Mellon that in Guizot's History of the English Revolution, "We are in the hands of a statesman engaged in the search for practical lessons who is in no doubt as to which side was right. The contrast with the French Revolution is continually before his eyes . . . . The English Revolution was political, not social. It sought liberty, not equality. It was religious, not rationalistic." Gooch, History and Historians, P. 179. Both men oversimplify Guizot's position and his attitudes. 
he ever advocated revolution, but he still saw many things wrong with it. The worst aspect was the violence of the civil war, and its brutalizing effect on the people. "Falsehoods, violence, grasping avarice, mean pusillanimity, egotism in every form, made rapid strides among all who were actually engaged in the strife." Those who were not directly involved, but were exposed to "the detestable influence of the revolutionary spectacle, lost, little by little, or retained in but dim, flickering memory, their pristine notions of right and of duty, of justice and of virtue."120 By the end of the civil war, the spirit of "faith and of religious liberty and degenerated, with some sects, into a fanaticism, arrogant, quarrelsome, intractable to all authority," a fanaticism concerned only with self-gratification by means of "wild invectives of dogmatic independence and of inflated pride."121 This would indicate that those who suggest that Guizot's admiration of the English Revolution was unqualified or extended to adulation gravely overstate the case. He is extremely critical of many of the figures of the Revolution, whom he describes as "at once rebels and despots; persecuting the bishops in the name of liberty, the independents in the name of power; arrogating to themselves, in a word, the privilege of insurrection and of tyranny, while daily declaiming against tyranny and insurrection."122

Guizot's admiration for the English Revolution should not be over-rated, but neither should it be dismissed completely. The English

$$
\begin{aligned}
& 120_{\text {Guizot, }} \text { English Revolution, p. } 11 . \\
& 121_{\text {Ibid. }} \text { p. } 14 . \\
& 122_{\text {Ibid., p. } 211 .}
\end{aligned}
$$


were not without grounds for rebellion. The tyranny of "Charles was, if not the most cruel, at least the most unjust, the most chargeable with abuse that England had ever endured."123 Up to the seventeenth century in England, the people had been led by the other segments of society, the aristocracy, the clergy, and the monarchy. The Tudors, especially Henry VIII and Elizabeth, had stifled the natural struggles between the elements of society, establishing monarchical absolutism. A "sluggish peace" resulted in society, which carried over into the reigns of the less able Stuarts. The Commons had been instilled with the spirit of the Reformation and began to feel restless. Since the aristocracy and the clergy would no longer lead them in the pursuit of English liberties, they determined to lead themselves, assuming "in its own person all the functions which its former leaders no longer fulfilled, claimed at once of the crown liberty, of the aristocracy equality, of the clergy the rights of human intellect. Then burst forth revolutions."124

In the revolution, the middle classes took a leading role. In the "last hundred years, great changes had taken place in the relative strength of the various classes in the bosom of society, without any analogous changes" in the political structure. Commercial activity and prosperity, along with the religious spirit of the times, had, "In the middle classes, given a prodigious impulse to wealth and thought." The middle classes "ranged themselves . . . around the parliament," while

$$
\begin{aligned}
& 123_{\text {Ibid. }} \text { pp. 45-46. } \\
& { }_{124}^{\text {Ibid., p. xiv. }}
\end{aligned}
$$


the nobility supported the monarchy in this struggle. ${ }^{125}$ The middle classes had been the vanguard of the internal regeneration of English society, and now they were called upon to lead the struggle for external reform as we11.

The struggle did not have a theoretical basis to begin with, according to Guizot. "No philosophical theory, no learned distinction between democracy, aristocracy, and royalty, occupied the advocates of 1iberty7; the house of commons alone filled their thoughts."126 By the House of Commons, they meant the entire nation, "the nobles as well as the people, the ancient coalition of the barons as well as the nation at large." The English aristocracy had previously been the most jealous guardian of English liberties, and it was only after a considerable period of time had elapsed that the commons came to realize that in this struggle the nobility were, for the most part, on the royalist side. When that realization came, the House of Commons took on a much more limited meaning, and its supremacy "established itself in every mind," in the party of 1iberty. 127 Once this first split within the nation became clear, it was not long before others began to appear. The most important splits came in the area of religion. The union of the antiroyalist party "was only complete and sincere on the question of political reform, or in other words, in that cause wherein leaders and party had neither intractable passions to satisfy, nor absolute

$$
\begin{aligned}
& 125_{\text {Ibid. , p. } 8 .} \\
& 126_{\text {Ibid. , p. } 57 .} \\
& 127_{\text {Ibid. }}
\end{aligned}
$$


principles to carry out."128 Even in the area of politics, once it became clear that the king could not win, divisions began to crop up rapidly.

Guizot was especially critical of the groups which called for what he considered visionary reforms. 129 Man's desire for reform is at the same time noble and dangerous. His ambivalence is shown in his discussion of the "Agreement of the People" of November 1647. When the "Agreement" was published,

those vague, glowing notions of absolute justice, those impassioned desires for equal happiness, which often suppressed, are never extinguished in the heart of man, burst forth in all directions, with a blind and furious confidence; and the leaders themselves, who would not listen to, knew not how to answer them, for, at bottom, they shared the principles in whose name these wishes were proclaimed. 130

If man were perfect, his drive for change and reform would be unquestionably good. Unfortunately, says Guizot, this is not the case.

Cromwell has already been discussed. It remains only to reassert Guizot's ambivalence. Some of Cromwell's actions are considered necessary, some are characterized as despotic. During his active life, the "religious opinions of Cromwell had feebly influenced his conduct, and he had often placed them at the service of his wordly interests, but they had never disappeared from this soul burdened with prevarications

\section{${ }^{128}$ Ibid. , p. 211.}

${ }^{129}$ Guizot was not clear about many of the groups. For example, he confused the Levellers and the Diggers and cites Everard as leader of the former when he was really a Digger. (England, III, 126). For both groups see H. N. Brailsford, The Levellers and the English Revolution (Stanford: 1961) and Lewis H. Berens, The Digger Movement in the Days of the Commonwealth (London: 1961). 
and lawless deeds." When he was on his deathbed, his religious convictions "resumed all their sway."131 Guizot's picture of Charles I is equally critical. The king was an untrustworthy and tyrannical monarch. When dealing with the trial and execution of the king, however, his attitudes are quite different. Charles looks almost like a martyr. This is probably much more the result of Guizot's abhorrence of violence than of a change of heart toward the tyrant. It should not be forgotten that Guizot's father was guillotined during the Terror of the French Revolution.

When all of Guizot's reservations about the period of 1640 to 1660 have been put forward, there remain three "facts" which the period confirmed. The first is that royalty can not be separated from Parliament. Therefore there can be no more absolute monarchy. The second fact was the emergence of the House of Commons to predominate in Parliament. "By the side of, or rather above, these two political facts, was the religious fact also consummated by the revolution, the complete and decisive domination of Protestantism in England."132

If Guizot was critical of the spirit of revolution, he was equally adamant against the spirit of reaction. After the death of Cromell, the English took Charles II out of "regard for the monarchical principle, and from weariness of revolutionary shocks."133 They had no real political guarantees against a return to tyranny under Charles II, and tyranny is what he tried to bring about. Under the restoration, it was

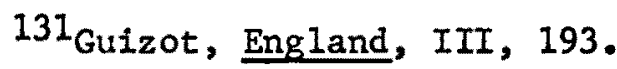

132Guizot, English Revolution, pp. 49-50.

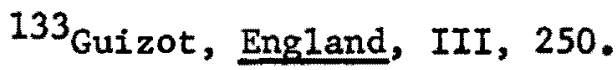


not the spirit of revolution so much as that of reaction which compromised the monarchy. Guizot points to a kind of white terror after the restoration, including such acts as hanging and decapitating the corpses of Cromwe11, Ireton, and Bradshaw. "Everywhere popular vengeance exhibits the same hideous and cowardly traits. The English royalist party were furnishing an example to the revolutionary populace, who were one day in France shamefully to profane the vaults of St. Denis."134 In passages which could apply to Louis XVIII and Charles X as well as Charles II and James II, Guizot talks of "the incapacity of an exile to govern a country whose life he had long ceased to share or to understand."135 He points out that "Exiled princes, thrown among strangers, by revolution, often forget the language of the people whom they aspire to govern." 136 As a result of this factor and the over-zealous reaction by the royalist party, the House of Stuart was thrown out again in 1688 . "Four kings rof that line] had for a long time and with varying pretensions laid on England the weight of an unjust yoke. For the second time, and forever, a free people had rejected them."137

The Revolution of 1688 was Guizot's Idea of a truly good revolution. It was, for England, a revolution to end a11 revolutions. "With the new reign commenced a new era. The revolution of 1688 had been

134 Ibid., III, 254. To some extent they were also furnishing an example to the royalists of France in 1815. See Daniel P. Resnick, The White Terror and the Political Reaction after Waterloo (Cambridge: Harvard University Press, 1966

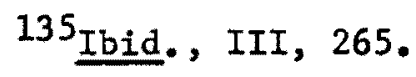

136 Ibid., IV, 93.

137 Ibid., III, 358. 
singularly moderate and reasonable; it had not claimed one new right; it had not added one liberty to the privileges and Iiberties England enjoyed." The revolution had not tampered with customs nor "renounced any of the forms and ceremonies in use from ancient times and dear to the popular heart." It had merely proclaimed once and for all that the "English nation regarded its rights and liberties as its most precious treasure, and that it placed them above hereditary titles and royal rights." The revolution had been both liberal and legal, not destroying the monarchy, but reestablishing the principle of "the common interest of the monarch with his people ... The bitter days of revolution were ended for England."138

The bitter days of revolution were over for England, but they had not yet begun for France. It would be a full century after the Glorious Revolution in England before revolution began in France. The century between 1688 and 1789 was "the most tempting and seductive of ages, for it promised to satisfy at once the strength and weakness of human nature." The period was one which elevated and enervated the human mind at the same time, "flattering altemately the noblest sentiments and the most grovelling propensities; intoxicating with exalted hopes, and nursing with effeminate concessions."139 Philosophy in the eighteenth century boasted that "it would regulate political economy, and that institutions, laws, and public authorities should only exist as the creatures and servants of instructed reason,--an insane pride, but a startling homage to all that is most elevated in man, to his intellecturl

${ }^{138}$ Ibid., III, 365.

139 Guizot, Memoirs, I, 6. 
and moral attributes."140 Guizot wishes that philosophy could have done what it claimed, but he knows that such a claim is unjustified. Man can not be raised to such divine heights merely by philosophy, nor can it be done in such a short time. By 1789, the three main ideas which had been instilled into the people were, "nul n'est tenu d'obéir aux lois qu'il n'a pas consenties;--le pouvoir légitime reside dans le nombre;--tous les homes sont égaux." The first idea he calls anarchy, the second is destructive of liberty, and the third "est destuctive de I'élévation politique dans le gouvernement et du progrds régulier dans la société."141 In 1789, the different classes of society still differed in their situations, habits, prejudices, and tastes, "mais le même feu les échauffe, le même vent les emporte; 1'esprit de réforme et de progrès possède la France tout entière."142 For this the Englightenment was responsible. While Guizot considered the Englightenment to be one of the most important immediate causes of the French Revolution, he traced an evolutionary pattern in French history which pointed toward the phenomenon as well. Under the "old state of French society," the dominant principle was a "fidelity to particular persons, superiors or equals." There was an equation of personal with social ties and obligations. "During the long course of our history, civilization expanded; the number of independent and influential persons increased immensely." Individuals began to dissociate themselves from the "private groups" to which they had belonged, "to live and mix in a general sphere." National 140 I bid., I, 153. $141_{\text {Guizot, Histoire Parlementaire, }}$ I, xviii - xix. 142 Ibid., I, vi. 
unity began to raise itself "above hierarchical organization. The state, the nation, the country, those collective and abstract existences, became real, living beings, objects of respect and affection." Ties of fidelity and attachment to persons began to give way, for the "great majority of minds," to duty and devotion to France as a nation. "The influence of public interests, desires, and dangers, had become stronger than that of private relations and affections." It was the result of "profound causes, and under the dominion of great social facts, that instinctively and without premeditation, the two parties in 1789 called themselves royalists and patriots." With the former group, "duty and attachment to the King, the head and representative of the country," with the latter, "duty and direct attachment to the country itself, formed the principle, the bond, and prevailing sentiment."143

The patriots of the new France won the struggle by means of force, which Guizot found always to be repugnant. He conceded that "it is impossible to avoid perceiving that physical force has stained the origin of all the powers of the world, whatever may have been their character or form."144 The Revolution was merely another case of good coming out of evil.145 In his Mémoires he evaluated the Revolution in this way: "J'étais et je demeure convaincu que les principes et les

$$
143 \text { Guizot, Memoirs, II, 13-15. }
$$$$
{ }^{144} \text { Guizot, Civilization in Europe, p. } 56 .
$$

145 Stanley Mellon was fairly accurate when he defined the "Liberal catechism of the Revolution" as: "The Revolution had roots in France and Europe; it was inevitable and popular, even partly aristocratic. There were crimes, but we did not commit them; besides there were provocations. Worse crimes were committed in the past, and the crimes of the Revolution were justified by its achievements." Mellon, Political History, p. 30 . 
actes de 1789 ont apporté, dans la société civile, les réformes essentielles; la révolution sociale est accomplie; les droits de la liberté et de l'egalité civile sont conquis."146 The conquest was precarious and incomplete. It had to be nurtured carefully and slowly. To demand immediate fulfillment of all the promises which the Revolution had made would be to destroy the fragile new France and make further progress impossible for a considerable period of time. Considerable amelioration of the extermal condition of French society had been made, primarily due to the fundamental element of new France, the middle classes. Before France could go further toward external reform, the bourgeoisie had to lead it through another period of internal regeneration. Just as the revolution of the $1640^{\prime}$ 's in England had not been the final solution there, the revolution of 1789 in France had not ended the struggles for liberty. England had its Cromwe11, and France had Napoleon. The restoration of Charles II followed Cromwell's death. Louis XVIII took the French throne on Napoleon's defeat. Both of these monarchs were succeeded by men who brought further reaction, and both James II and Charles $\mathrm{X}$ lost their thrones through revolution. James II was expelled in 1688, in a move which brought final peace and an end to revolution for England. The July Revolution of 1830 in France corresponded to the Glorious Revolution of 1688 in several ways, and Guizot felt that it should have accomplished the same ends. To his great

146Francois Guizot, Mémoires pour servir a $1^{\prime}$ Histoire de mon temps (8 vols; Paris: Michel Levy Freres, 1872), VIII, 540. 
disappointment, it did not. 147 The spirits of revolution and reaction were too strong in France and the experience and tradition of liberty were too weak for the turmoil to end so soon. The July Monarchy came to an end, and with it Guizot's career in politics, in 1848. That revolution gave way, in turn, to the Second Empire. Before Guizot died, that Empire had fallen to the Prussians, and the Third Republic had been founded. Guizot's attitudes toward this sequence of events must now be considered.

With Napoleon's defeat in 1814, Louis XVIII returned to France to take the throne. Many republicans and Bonapartists were extremely displeased to have the Bourbons back. The manner in which the Restoration came about, appearing as if it were imposed by enemies of Napoleon and of France, increased hostility toward the Bourbons. Guizot retorted that it "is truly an absurd injustice to charge the Restoration with the presence of those foreigners which the mad ambition of Napoleon alone brought upon our soil, and which the Bourbons only could remove by a prompt and certain peace."148 He lays the responsibility for the Treaty of Paris of 1814 at Napoleon's feet..

147In his History of the English Revolution, he had written that it "is the pretension now of the kings, now of the people--the former in the name of divine right, the latter in that of popular sovereignty--to intimidate each other by indicating beforehand the deadly blows they can strike: a pretension as senseless as insolent, which enervates and shakes, now the government, now the liberties of the country. It behoves alike kings and peoples, in their mutual relations, to advance only their legal rights, and to bury in profound silence the mysteries and the menaces of coups d'etat and revolutions." His opposition to arbitrary power extended to the goverment as well as to the people. Guizot, English Revolution, p. 62 .

148 Guizot, Memoirs, I, 29. 
The most positive achievement of the early Restoration was the Charter. "Judged by itself, notwithstanding its inherent defects and the objections of its opponents, the Charter was a very practicable political implement." In the Charter, both power and liberty "found ample scope" for their "exercise and defence." The problems of the Restoration came from the "workmen," who "were much less adapted to the machine than the machine to the work. "149 The workmen were either too much inclined to revolution or to reaction, and not enough toward liberty:

De la Restauration, les hommes de I'ancienne France s'étaient promis la victoire; de la Charte, la France nouvelle attendait la sécurité; ni les uns, ni les autres n'obtenaient satisfaction; ils se retrouvaient, au contraire, en présence, avec leurs prétensions et leurs passions mutuelles.150

This condition of French society made Napoleon's return from Elba possible. Any progress or amelioration which the Restoration had brought about was cancelled by the Hundred Days. This waste of "blood and treasure" intensified "the old quarrel which the Empire had stifled and the Charter was intended to extinguish,--the quarrel between old and new France, between the emigrants and the revolutionists."151 The Hundred Days brought on a reaction which "destroyed in the twinkling of an eye the work of social reconciliation carried on in France for sixteen years, and caused the abrupt explosion of all the passions, good or evil, of the social system, against all the works, beneficial or mischievous, of the Revolution." 152

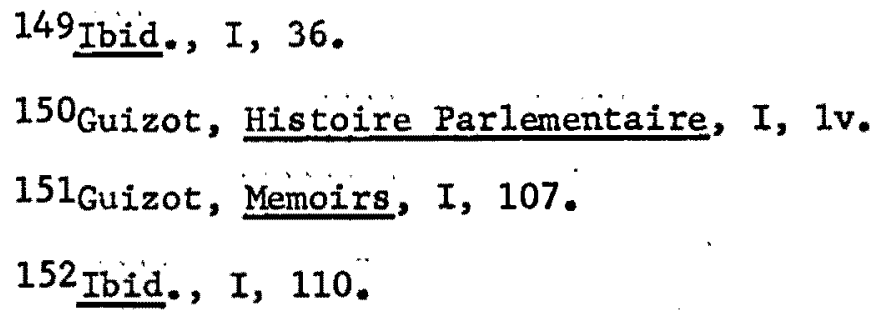


Much of the reason for the failure of the Hundred Days was the refusal of the middle classes to blindly follow Bonaparte in his new endeavors. Guizot takes pride in this fact, defending the middle classes from the Bonapartists. Those classes spoke for the nation. Their "unsettled feeling" was "a legitimate and patriotic disquietude. What they wanted, and what they had a right to demand, for the advantage of the entire nation as well as for their own peculiar interests," was that "peace and liberty should be secured to them; but they had good reason to question the power of Napoleon Fas well as the intention7 to accomplish these objects."153 The middle classes took the lead again in bringing France back to the right path.

Guizot belonged to those middle classes, and he desired a reconciliation of the two Frances as much as anyone. In his lectures of 1820 at the Sorbonne, he tried "to separate revolutionary excitement and fantasies from the advances of justice and liberty, reconcilable with the eternal laws of social order." Alongside of this "philosophic undertaking," he pursued a purely historical one. He "endeavored to demonstrate the intermitting but always recurring efforts of French society to emerge from the violent chaos in which it had been originally formed, sometimes produced by the conflict, and at others by the accordance of its different elements--royalty, nobility, clergy, citizens, and people." He "particularly wished to associate old France with the remembrance and intelligence of new generations." For there was "as little sense as justice in decrying or despising our fathers, at the very moment when - . we were taking an immense step in the same path

${ }^{153}$ Ibid., I, 61 . 
which they had followed for so many ages."154 He knew that only a small part of old France would be reconciled with the new France, "mais c'est une minorité dont 1 'appui moral et numérique est décisif."155

Guizot was as reluctant to accept some of the elements of new France as he was to discard some elements of the old.156 It was this element which united the Doctrinaires, the liberal, parliamentary monarchists led by Royer-Collard. Of this group, to which he belonged, Guizot said that the "peculiar characteristic... and the real source of their importance in spite of their limited numbers, was that they maintained, against revolutionary principles and ideas, ideas and principles contrary to those of the old enemies of the Revolution." They opposed the Revolution not to destroy it, as much of old France wished to do, "but to reform and purify it in the name of justice and truth."157 To hold resolutely to the middle of the correct path was what Guizot sought to do. To achieve this, one had to be at least cautiously optimistic. On October 20,1822 , one week after his lectures at the Sorbonne were halted by the governnent, Guizot wrote to Amable de Barante, "Je suis aussi frappé que vous de la dissolution de la société, de son inertie; je me demande d'où lui reviendra ce qui fait

$$
{ }^{154} \text { Ibid., I, } 301 .
$$

\section{Guizot, Histoire Parlementaire, I, x.}

$156 \mathrm{G}$. P. Gooch argues that Guizot "remained through life a moderate liberal of 1789 ... The predominance of the educated bourgeoisie was the true mean between the rival absurdities of divine right and the sovereignty of the mob. The foes of society were absolutism and Jacobinism." Gooch, History and Historians, p. 178. His evaluation is quite correct.

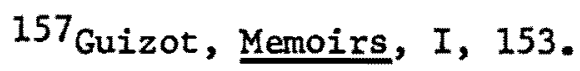


que les hommes agissent, et agissent en commun." He continues, "je suis hors d'état de me répondre, et pourtant je suis sûr que cela sera, que ce pays-ci n'est point en train de périr, ni de s'asservir."158

With the death of Louis XVIII and the ascension to the throne of his brother, Charles $\mathrm{x}$, the spirit of reaction became clearly dominant in the government. The antithesis, the spirit of revolution, increased among the people. The synthesis which resulted was the Revolution of July 1830. "Appelé en mêne temps à relever le pouvoir et à étendre la liberté, le gouvernement de Juillet avait à lutter à la fois contre les représentants obstinés de 1'ancienne société française et les téméraires enfants de la nouvelle, contre la Restauration et la Révolution."159

The position of the new govermment was extremely precarious, especially since it was the result of a revolution itself. The July Revolution had the honor of being one of the very few which was motivated to defend violated laws and liberties, but it was still a revolution, with resulting inevitable damage to the principle of monarchy. "Entreprise au nom des droits de la monarchie constitutionelle, la révolution de 1830 a ouvert la porte aux tentatives républicaines et aux perspectives indéfinies de $I^{\prime}$ imagination humaine, honnêtes ou perverses."160 Guizot's predicament, as well as that of most of the

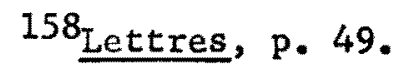

${ }^{159}$ Guizot, Histoire Parlementaire, I, cx. Though Guizot would not have said so, there is an implicit dialectic in much of his thought. Progress comes out of the struggle between principles and systems and the elements of society.

160 Guizot, Mémoires, VIII, 597. 
July "revolutionists," is depicted in La Coalition, a play which was performed shortly after the deposition of Charles $x$. In the play, Martel, a blacksmith says, "I shall not lay down my hammer until the revolution has been completed." To this, his mother responds, "Is that so? Is the revolution not completed? Is not the king [Louis-Philippe] on his throne? Are not the merchants in their shops? The clerks in their offices? The troops in their barracks? Why are not the workers in their shops?"161 For Guizot, the revolution was complete. For it to go any further would be to bring about severe danger for the advances already made. Having conceded the inch, it would be disastrous to concede the mile. That was what he felt in 1830 , and that was what he thought eighteen years later, when the mile was demanded more vigorously. As a result, the Revolution of 1848 ended his political career.

Guizot's hostility toward the 1848 revolution was not merely based on personal loss or resentment. Any attempt to form a republic at that time he felt would be out of step with the development of French history, and therefore its success was doubtful. "C'est que, dans l'état de la société française, avec son histoire ancienne et contemporaine, après ses quinze siècles de monarchie et ses soixante ans de révolution, la République ne contient, pour la France, les conditions ni du gourvernement ni de la liberté."162 This judgment was not a retrospective one.

$161_{\text {Quoted by César Graña, Modernity and Its Discontents: French }}$ Society and the French Man of Letters in the Nineteenth Century (New York, Evanston, and London: Harper and Row, 1967), p. 11.

${ }^{162}$ Guizot, Histoire Parlementaire, I, cxorv. 
In his Democracy in France, Guizot stated that the "Democratic Republic" of France could give that country neither peace nor liberty. Its only fruits would be chaos or tyranny or both. 163 This work was published before Louis Napoleon's coup d'état fulfilled Guizot's prophecy.

In a letter to Lord Aberdeen of September 16, 1849, Guizot showed his concern for France and his refusal to lose all hope for his country:

La France sait qu'elle est dans une auberge où elle ne doit pas rester, mais elle veut s'y reposer un peu. En attendant, un bon et un mauvais travail se poursuivent dans le pays; le bon, c'est le rapprochement, $I^{\prime}$ union de jour en jour plus serieuse des grandes fractions du parti conservateur et monarchique, malgré leurs préventions et prétensions réciproques qui ne sont pas encore dissipées; le mauvais travail, c'est l'effort continu des socialistes pour corrompre le peuple dans les campagnes commes dans les villes, effort peu efficace dans cette province-ci Normandy 7 mais qui 1 'est beaucoup ailleurs. Ainsi, en mêhe temps le mal s'accroit et le remède se prépare. Dieu veuille que le remède se trouve prêt quand le mal éclatera de nouveau! Je ne suis ni rassuré, ni désespéré. 164

The logical outcome of the republic was the Second Empire. "The Republic commenced in 1848 by anarchy, and led to nothing else. France accepted and supported the empire as a haven against this anarchy. There are times when nations are swayed pre-eminently by their wishes." There are other times when "they crouch signally under their fears."165 The Empire was an example of the second. On December 16, 1851, Guizot wrote to an English friend that "Mon pauvre pays est bien humilié; đ'autant plus humilié qu'il a mérité son humiliation et que tous les

$$
\begin{aligned}
& { }^{163} \text { Guizot, Democracy, p. } 22 . \\
& 164 \text { Lettres, pp. 269-270. } \\
& 165_{\text {Guizot, Memoirs, IV, 202-203. }}
\end{aligned}
$$


homnes sensés 1 'ont prévue. La démagogie devait amener la dictature."166 He was extremely critical of Louis Napoleon. In February of 1852 he described Bonaparte's nephew to his daughter, Madame de Witt: "Le président Guizot wrote7, conspirateur habile et hardi, conspire toujours et ne gouverne pas. Il fait la guerre à ses ennemis; il prépare de nouvelles aventures; il a des passions et des rêves; il n'a pas du tout cet esprit élevé, sensé, mesuré, tempéré, clairvoyant, qui est 1 'esprit de gouvernement."167 He predicted a short reign for Napoleon III. In the event, his reign was slightly longer than Louis-Philippe's, and it ended not because of a revolution but because of the defeat of France in the Franco-Prussian War.

Guizot handled the fall of the Second Empire "historically" in the fifth volume of his History of England. In that volume he wrote, "The Second Empire--imposed upon France by a coup d'état as bold as it was unscrupulous, accepted through lassitude and love of repose--had long deceived France and all Europe by an outward show of proud strength and prosperity." Then suddenly in 1870, "as by some unforeseen stagetrick, it fell before a foreign army, dragging down France in its own ruin. A third time the Bonaparte name and the principle of absolutism brought invasion upon France and unspeakable patriotic humiliation."168 By the time of his death in 1874, the beginnings of the Third Republic were to be seen, but Guizot had as little confidence in his old rival Thiers as did the monarchist Assembly which could not wait to be rid of him.

${ }^{166}$ Lettres, p. 327.

167 Ibid., Pp. 329-330.

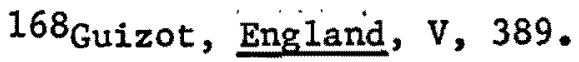


Having traced revolution and reaction in England to 1688 and in France to the $1870^{\prime}$ s, following Guizot's treatments of specific events, an examination of his general attitudes toward revolution and his summary of the significance of the English and French Revolutions are in order. The first point of importance is that neither revolution "interrupted the natural course of events in Europe, neither the English Revolution nor our own ever said, wished, or did anything that had not been said, wished, done, or attempted, a hundred times before they burst forth."169 Second, they not only did not interrupt history, they "advanced civilization in the path it had been pursuing for fourteen centuries; they professed the maxims, they forwarded the works to which man has, in all times, owed the development of his nature and the ame1ioration of his condition." Both revolutions "did that which has been by turns the merit and the glory of the clergy, of the aristocracy, and of kings."170 Third, both revolutions were caused by the decay of the "feudal aristocracy, the church, and royalty." Both revolutions "laboured at the same work, the dominion of the public in public affairs; they struggled for liberty against absolute power, for equality against privilege, for progressive and general interests against stationary and individual interests."171

On revolution in general, Guizot set forth the criterion for success in his Mémoires:

$$
\begin{aligned}
& { }^{169} \text { Guizot, English Revolution, p. x. } \\
& 170 \text { Ibid., p. xii. } \\
& 171 \text { Ibid., p. xvi. }
\end{aligned}
$$


Power must have inflicted on a country many violations of right, with repeated acts of injustice and oppression bitter and prolonged, before revolution can be justified by reason, or crowned with triumph in the face of its inherent faults. When such cases are wanting to revolutionary attempts, they either fail miserably or bring with them the reaction which involves their own punishment. 172

The important point is that any revolution will have "its inherent faults," which must be overcome if the revolution is to be termed a good or successful one. This is not impossible, for one of the "incentives which urge men to conspire, or rise openly for the overthrow of any established government. - is the idea of the right to restore in the very heart of that existing government, legitimate authority in place of usurped power."173 This is as close as Guizot ever comes to Locke's position, for the inherent faults of any revolution are constantly before the Frenchman's eyes. Such is "the innate vice of all revolutions, that even the most necessary, the most legitimate, the most powerful of them, throws the society it serves into great disorder, and itself long after remains menaced and precarious."174 Some revolutions are begun by men with noble sentiments and a true concern for right, but the "revolutionary spirit is fatal to the greatness it raises up, as to that which it overturns."175 In revolution, there is always the danger of running to extremes. Revolutionists, "even the ablest of them, are short-sighted. Intoxicated by the passion, or dominated by the necessity of the moment, they do not foresee that what today

$$
\begin{aligned}
& 172 \text { Guizot, Memoirs, I, } 226 . \\
& 173_{\text {Ibid. , II, } 311-312 .} \\
& 174 \text { Guizot, English Revolution, p. } 70 . \\
& 175 \text { Ibid. , p. } 78 .
\end{aligned}
$$


constitutes their triumph, will be tomorrow their condemnation."176 The short-sightedness of revolutionists usually leads them past the mark at which the revolution should stop, with the result that "no serious trouble can burst forth in any part of the social edifice, but inmediately the entire building is in danger of subversion; there exists a contagion of ruin which spreads with terrible rapidity."177 Instead of a revolution concerning itself with the restoration of legitimate authority, as should be the case, the end result is usually destruction. "Every storm becomes the deluge."178 Revolutionists become obsessed with "the love and sin of destroying, for the boastful pleasure of creating again." In times of revolution, "man looks upon all that exists before his eyes, persons and things, rights and facts, the past and the present, as so much inert matter, of which he may dispose freely, and mould and remould according to his will." Man begins to flatter himself with the notion "that the mind contains isolated and perfect ideas which give him absolute control over everything, and by authority of which he can destroy at any cost or hazard all that now is," to replace it with whatever he wishes. 179 Materially, Guizot is distressed by the destruction of revolution. Philosophically, he is distressed by the way revolution makes man lose his sense of the limits of his own power and significance. Man's liberty is not complete. It must always be limited by order. It is these two concepts, liberty and order, to which we now

$$
\begin{aligned}
& { }^{176} 6_{\text {Ibid., }} \text { p. 15. } \\
& 177_{\text {Guizot, Memoirs, }} \text { II, 3-4. } \\
& 178_{\text {Ibid., II, } 4 .} \\
& { }^{179} \text { Ibid., II, 19-20. }
\end{aligned}
$$


turn. For Guizot, they are not antithetical, but complementary. Liberty without order is chaos; order without liberty is tyranny. Nefther chaos nor tyranny does Guizot find acceptable. 
CHAPTER IV

\section{LIBERTY AND ORDER}

I have, alternately, defended liberty against absolute power, and order against the spirit of revolution,--two leading causes which, in fact, constitute but one, for their disconnection leads to the ruin of both. Until liberty boldly separates itself from the spirit of revolution, and order from absolute power, so long will France continue to be tossed about from crisis to crisis, and from error to error. 180

Liberty must separate itself from the revolutionary spirit. Order must dissociate itself from the spirit of reaction. Once these two events take place, liberty and order can and must be combined in society. Guizot realizes the difficulty of this task. "Le but de la société n'est pas simple; elle aspire en même temps et nécessairement à 1'ordre et à la liberté, à la durée et au progrès."181 This is difficult enough in any society, but the larger and grander a society becanes, the more difficult and more necessary this combination becomes. 182

If the two facts cannot be combined, the most necessary of the two is order. "The permanent want of every community,--the first and most imperious want of France at the present day,--is, peace Dy which is meant order 7 in the bosom of society itself. ${ }^{183}$ He cautions the

${ }^{180}$ Guizot, Memoirs, I, 3.

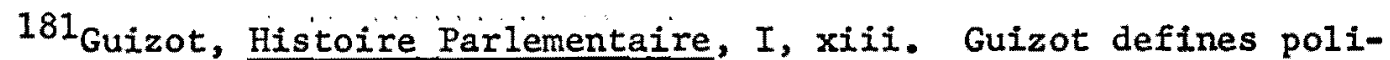
tical society as "the relation existing between men, in virtue of their interests, opinions, and sentiments, and the ruling power under which they live." Guizot, Democracy, p. 48.

182Guizot, Histoire Parlementaire, I, xiv. ${ }^{183}$ Guizot, Democracy, p. 15. 
"friends of freedom" that "nations prefer absolute power to anarchy. The first want--the first instinct--of communities, as well as of governments or of individuals, is self-preservation." He continues with the assertion that "a community may exist under absolute power; under anarchy, if it lasts, it must perish."184 If the friends of liberty wish to avoid absolutism, they must avoid anarchy and accept the necessity for power. "There must be a deeply-impressed and permanent feeling of a superior power ever capable of reaching and punishing offenders. In the interior of a family, in the relations of man with his God, there is naturally and necessarily fear. He who dreads nothing will soon respect nothing." Man's "moral nature" requires regulation and the individuals in society require guarantees of security. 185

There are two systems of political guarantees available to societies. It "is either necessary that there should be a particular will and power so superior to all others that none should be able to resist it, and that all should be compelled to submit to it as soon as it interferes," or else there "should be a public will and power." This public power would be the "result of agreement, of the development of particular wills," and it must be able to "make itself respected equally by all."186 The obvious choice for those who want freedom and good government is the public or general will rather than the particular will. The basic element of the "particular power" would be force,

$$
\begin{aligned}
& 184_{\text {Ibid. }} \text { p. } 66 . \\
& 185_{\text {Guizot, Memoirs, III, } 296 .} \\
& 186_{\text {Guizot, Civilization in Europe, p. } 90 .}
\end{aligned}
$$


which is not the basic element of good government. In good government, force is only one element, to be used sparingly.187

That

which above all things constitutes [good government], is a system of means and powers, conceived with the design of arriving at the discovery of what is applicable to each occasion; at the discovery of truth, which has a right to rule society, in order that afterward the minds of men may be brought to open themselves to it, and adopt it voluntarily and freely.188

The "noblest effort" which human society can make is to "assimilate political order to the divine order which governs the world."189 This requires some effort from the members of society, including the sacrifice of privileges. "Those universal feelings, natural ideas, and simple relationships which constitute the basis of humanity and of life, become changed and enervated in a social condition which consists entirely of exceptions and privileges." In a society based on privilege, "conventionalisms take the place of realities, and morals become factitious and feeble."190

Guizot's dismissal of privilege does not mean democracy. He distinguishes between "universal rights inherent in man's nature," and "individual rights." Universal rights can not be withheld, he asserts, although he fails to point out many other than security. He does not deal with abstract concepts. He is primarily concemed with individual rights, "which spring from personal merit alone, without regard to the

$$
187 \text { Ibid., p. } 105 .
$$

188 Ibid., p. 107.

${ }^{189}$ Guizot, Mémoires, III, 177.

190 Francois Guizot, Shakspeare and His Times (London: Richard Bentley, 1852), p. 6 . 
external circumstances of birth, fortune, or rank, and which every one who has them in himself should be permitted to exercise."191

Just as Guizot stresses diversity among men, he points out the need for diversity and separation of powers in government. "Social unity requires that there should be but one government; but the diversity of the social elements equally requires that this government should not be one sole power."192 Govermments must be mixed, with no dominating element. For this to come about, the government must be strong, and every element in it must also be strong. "Every weak power is a power doomed to perish by extinction or by usurpation. If several weak powers conflict, either one will become strong at the expense of the others, and will end in a tyranny," or else all of the weak powers "will trammel and neutralize each other, and the result will be anarchy."193 As long as the elements which make up the government are of approximately equal strength, tyranny is no great danger:

Quand les gouvernements de ce genre ont atteint à leur maturité, I'unité de pouvoir et d'action s'établit entre leurs divers éléments; Imais7 le pouvoir suprême et definitif, un au fond quoique extérieurement divisé, est soumis, par son organization intérieure, à certaines conditions qui lui posent, dans son propre sein, des limites qu'il ne peut dépasser sans perdre les forces même par lesquelles il agit. 194

Such a model would easily fulfill the duty of government, which is "to be at the same time decided and liberal, firm and gentle, in their acts as in their views, and to feel sympathy with, while they deal justly

$191_{\text {Guizot, Memoirs, }}$ I, 164. 192 Guizot, Democracy, p. 60. 193 Ibid., p. 63. 194Guizot, Histoire Parlementaire, I, 1xxv-1xxvi. 
towards, the opposing interests and sentiments which dispute empire in society and in the human heart."195

Much of the explanation for Guizot's stress on combining a number of elements in the govermment is found in his deliberations about sovereignty. The only true sovereign is God, which he characterizes as "right," of which he affirmed, "and the merest common sense will acknowledge, that the sovereignty of right completely and permanently can appertain to no one; that all attribution of the sovereignty of xight to any human power whatsoever is radically false and dangerous." Because of this, there arises "the necessity for the limitation of all powers, whatever their names or forms may be; hence the radical illegitimacy of all absolute power, whether its origins be from conquest, inheritance, or election."196 The sovereign of right, God, has characteristics which could be "derived from his very nature." The first of these is that "he is unique; since there is but one truth, one justice, there can be but one sovereign of right." Secondly, he "is permanent, always the same; truth never changes." The sovereign of right is "placed in a superior situation, a stranger to all the vicissitudes and changes of this world; his part in the world is, as it were, that of a spectator and judge."197 The closest earthly representation of the sovereign of right is found in monarchy. It is "royalty which externally reproduces, under the most simple form, that which appears its most faithful image, these rational

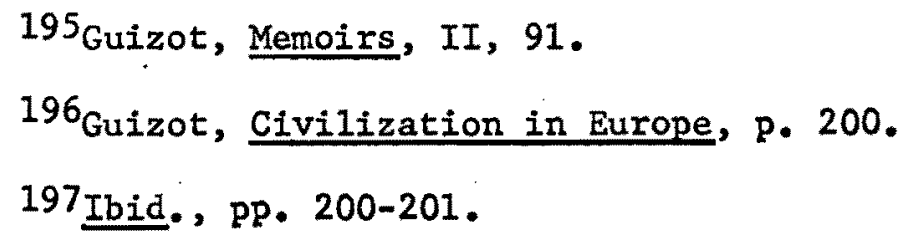


and natural characteristics of the sovereign of right."198 For this reason, Guizot was a monarchist. The monarchy must be limited, since even as the closest representation it is a poor one. "It cannot be too often repeated, to bring down human pride to its just level, that God is the only sovereign, and nobody on earth is God, neither people nor kings."199 The best way of limiting a monarchy is with a parliament. The establishment of a good working model of this sort is difficult, but "il sera nécessaire au triomphe de la liberté politique."200

To those who maintained that the only form, in theory or in reality, of "le gouvemement libre" is the republic, Guizot replied that the form of the "gouvernement libre" is determined by the situation. There are several different forms it could take. To illustrate his point, he offers the examples of England and America. "La monarchie anglaise et la république americaine sont deux gouvermements bien réellement libres et qui satisfont à toutes les exigences actuelles de la liberté politique." 201 In these two governments, "c'est par des moyens très-differents que s'etablit et s'exerce la reponsabilité du pouvoir, cette garantie necessaire de la liberté politique."202

We have already noted Guizot's admiration for British institutions and history, as well as his respect for the American whom he placed in the category of great men, George Washington. He was pleased and in

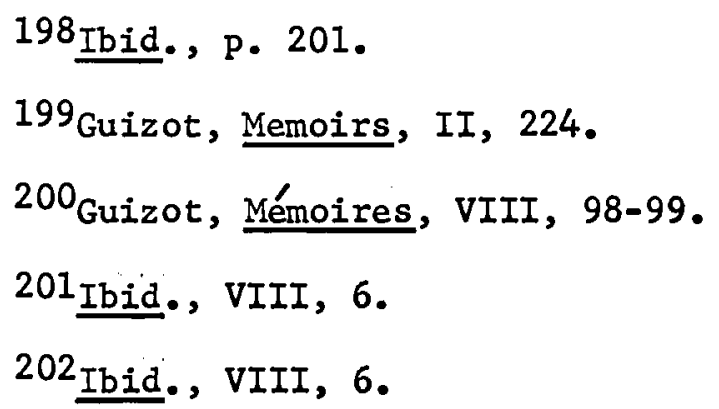


sympathy with the American experiment. "I should undoubtedly have been a republican in the United States of America when they separated themselves from England. A federative republic was, for them, a natural and consistent government," he declared. That system was "the only form suited to their habits, their requirements, and their feelings."203 Long before the American Revolution, "the Americans were no longer merely subjects of the mother-country, only fighting against this or that abuse of power and violation of right." The circumstances of geography and history had made them a nation, which by the 1770's was "rising up against the oppression of another nation, whatever might be the name or form of that oppression."204 Writing shortly after the conclusion of the American Civil War, Guizot lauded the ability of the United Statss to meet the crises it had faced then and in the past:

Amid many faults, many grave and dangerous political errors, and in spite of shocks, the most recent and most severe of which came near destroying that union so dear to Washington's patriotic heart, the American nation has continued a great nation, and, in the course of one century, its position has become vastiy more important than its founders foresaw. 205.

The republican form of government had made the United States a great nation, but France needed something different. "As a republic was to the United States in 1776 , so is a monarchy, in our days, the obvious and true system for France, the most favourable to public liberty and peace." In France, the monarchy is "best suited for the development of salutary and legitimate strength, and for the repression

$$
\begin{aligned}
& { }^{203} \text { Guizot, Memoirs, II, 23-24. } \\
& { }^{204} \text { Guizot, England, IV, } 230 . \\
& { }^{205} \text { Ibid., IV, } 279 .
\end{aligned}
$$


of perverse and destructive agencies."1206 For France to do away with the monarchy is to try to escape from French history. Such an attempt is dangerous and its success is not possible. "It is fruitless for a people to deny or forget the past; they cannot either annihilate or abstract themselves from it; situations and emergencies will soon arise to force them back into the road on which they have travelled for ages."207 The French should accept their political heritage, working to build a responsible "gouvernement libre" with the monarchy as the basis.

One of the basic elements of such a government is the development of political parties. Strong political parties are necessary for liberty whether the government be a republic or a monarchy with a parliament. 208 "In a free country, or in one struggling to become free, the elements of political society are political parties, in the widest and highest acceptation of the term."209 Political parties are not easy to form, even if the people are desirous of liberty. "I know not Ccomplained Guizoty which is the most difficult undertaking,--to transform the functionaries of absolute power into the supporters of a free Government, or to organize the friends of liberty into a political party."210 The difficulty is that there is a tendency toward factionalism when men are formed into opposing groups. Guizot recognized "no

$$
\begin{aligned}
& { }^{206}{ }_{\text {Guizot, Memoirs, II, } 24 .} \\
& 207_{\text {Ibid. , I, } 113 .} \\
& 208_{\text {Guizot, Mémoires, VIII, } 7 .} \\
& 209_{\text {Guizot, Democracy, }} \text { p. } 48 . \\
& 210_{\text {Guizot, Memoirs, }} \text { I, } 201 .
\end{aligned}
$$


greater danger to free institutions than that blind tyranny which the habitual fanaticism of partisanship, whether of a faction or a small segment, pretends to exercise in the name of liberal ideas."211 Guizot saw the danger as particularly strong among the French, among whom he saw a tendency to hold on to principles with a firmness bordering on fanaticism.212 "Politics require a certain mixture of indifference and passion, of freedom of thought and restrained will, which is not easily reconciled with a strong adhesion to general ideas." For liberty to be assured, its advocates must have a "sincere intent to hold a just ballance between the many principles [held by different segments of society] and interests of society."213 Political parties must have, as their basis, a "certain measure of faith in ideas, and of fidelity to persons." Without both, they degenerate into factions. 214 Political parties must be embodied with political spirit, which "shows itself in the will and the power to take a regular and active part in public affairs, without

211 Ibid., I, 46.

212Guizot is not alone in this. See André Siegfried, "Approaches to an Understanding of Modern France," in Modern France: Problems of the Third and Fourth Republics, ed. Edward Mead Earle (New York: Russel1 \& Russe11, 1964).

$213_{\text {Guizot, Memoirs, }}$ I, 172.

214 Guizot, English Revolution, p. 54. Alexis de Tocqueville pointed to the dangers of the opposite extreme, as manifested during the July Monarchy in the French parliament: "As all business was discussed among members of one class, in the interest and in the spirit of that class, there was no battlefield for contending parties to meet upon. This singular homogeneity of position, of interests, and consequently of views, reigning in what $M$. Guizot had once called the legal country, deprived the parliamentary debates of all originality, of all reality, and therefore of all genuine passion." The Recollections of Alexis de Tocquevilie, ed. J. P. Mayer (Cleveland: The World Publishing Company, 1959), P. 7. 
employing violence or risk of disturbance."215 Liberty, says Guizot, is a proud and jealous mistress, "qui sait ce qu'elle vaut et ne se donne qu'à ceux qui, à leur tour, se donnent à elle tous et tout entiers." 216 To give one's all to liberty means, on many occasions, to restrain oneself, to allow oneself to be constrained by the needs of society. The most obvious means society has to restrain its citizens is law, the object of which "is to provide what is necessary, not to step in advance of what may become possible; their [laws] mission is to regulate the elements of society, not to excite them indiscriminately." 217 Their mission is a conservative one, primarily negative in function. "Preventive and general intimidation is the great and predominating object of penal laws." If this were not the case, honest rather than dishonest peoplewould be intimidated. 218 Guizot was always quick to see conspiracies, which were, in fact, numerous during the Restoration and the July Monarchy. Conspiracies were a prime target for Guizot's notion of law. "Under a system of legality and liberty, judicial repression is the only effectual weapon to employ against conspiracies. It is necessary that plotters should fear the law and its interpreters."219 Obedience to law must be complete. Guizot had more confidence in law than in men. "Ce n'est pas la volonté des hommes, c'est la justice et la sagesse intrinsèques des lois et du pouvolr qui fait leur

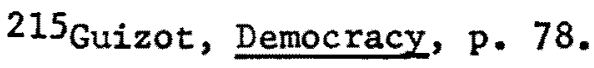

$$
\begin{aligned}
& 216 \text { Guizot, Histoire Parlementaire, I, cxxii. } \\
& 217_{\text {Guizot, Memoirs, }} \text { III, } 63 . \\
& \text { 218Ibid., II, 295-296. }
\end{aligned}
$$

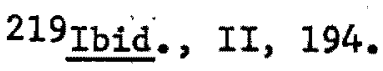


droit à I'obéissance." 220 Society must be careful not to undermine its laws by evading the enforcement of them or by using them to handie problems they were not meant to handle. "It is better to suspend openly, and for a given time, a particular privilege, than to pervert, by encroachment and subtlety, the fixed laws, so as to adapt them to the emergency of the hour." 221

On the question of the liberty of the press, Guizot was consistently liberal, to the consternation of many of his contemporaries. "Free nations and governments [Guizot said] have but one honourable and effective method of dealing with the liberty of the press,--to adopt it frankly, without undue complaisance." To do otherwise would allow people who want to cause trouble to make an issue of it. "Let them not make it a martyr or an ido1, but leave it in its proper place, without elevating it beyond its natural rank."222 only as it begins should a government worry about the press:

In a well-established government, solidly constituted, the danger against which the friends of liberty have to contend is oppression: all is there combined for the maintenance of law; all tends to support vigorous discipline, against which every individual labours to retain the share of freedom which is his due; the function of government is to support order; that of the governed to watch over liberty. 223

In a government just commencing, care must be taken that liberty does not become license. In extraordinary circumstances, the press may then be restrained. Once the government is well established, the press must

220 Guizot, Histoire Parlementaire, I, xx.

$221_{\text {Guizot, Memoirs, }}$ I, 114-115.

222 Ibid. , I, 49.

223 Ibid., I, 394-395. 
not be tampered with. Guizot does not believe that the press will always be right, because human nature is not always enlightened. "The liberty of the press is human nature displaying itself in broad daylight, sometimes under the most attractive, and at others under the most repelling aspect." It is the "wholesome air that vivifies, and the tempest that destroys, the expansion and impulsive power of steam in the intellectual system." On the whole, a free press will be "more useful than injurious to public morality."224 on this question, as on many others, Guizot was a liberal for rather conservative reasons. Guizot advocated a free press not because he was confident that it would improve man and society. Rather, he feared that to deny freedom to the press would be to make it a cause or a martyr to those elements in society which were always bent on revolutionary activity. A free press would do less harm to society than would the revolutionaries if given the opportunity. In effect, he was co-opting a liberal cause for conservative reasons.

In education, Guizot was more openly conservative.225 The "grand problem of modern society is the government of minds," says Guizot. "It has frequently been said in the last century, and it is often repeated now, that minds ought not to be fettered, that they should be left to their free operation, and that society has neither the right nor the

\section{Ibid. , I, 170.}

${ }^{225}$ César Graña argues that "when he [Guizot7 advised borgeois parents to promote an academic education among their sons, he wanted to impress on them the revolutionary power of modern ideologies could only be contained by intellectual dedication to the proper social order." Grana, Modernity and Its Discontents, p. 12. 
necessity of interference." Experience has proven this "haughty and precipitate" claim to be false. "It has shown what it was to suffer minds to be unchecked, and has roughly demonstrated that even in intellectual order, guides and bridles are necessary."226 One of the guides, probably the most important, is religion. "Popular education ought to be given and received in the bosom of a religious atmosphere, in order that corresponding impressions and habits may penetrate from every side. $" 227$

The authorities on the question of popular education should be the family, the state and the church. In a speech given in the Chamber of Deputies on January 31, 1846, Guizot put the family first. "Les enfants appartiennent à la famille avant d'appartenir a I'État."228 Much of the child's education must come from the family, especially the religious aspect. It is "le droit des parents de faire élever leurs enfants dans leur foi, par le ministres de leur foi."229 In 1850, refusing an appointment to a committee on education, he expanded on the point. "Les établissements d'education extérieurs à la famille n'existent que pour la supléer et pour faire ce qu'elle ne peut pas ou ne veut pas faire elle-même."230 In a July address to the Institut that same year, Guizot discussed the two "grands suppléants, deux grands auxiliaires naturels

$226_{\text {Guizot, Memoirs, }}$ III, 14.

$227_{\text {Ibid. }}$, III, 66 .

${ }^{228}$ Guizot, Mémoires, VII, 378.

229 Ibid., VII, 379.

230Lettres, p. 291. 
de la famille, I'Église et I'État."231 The Church is important because "l'enseignement religieux lui appartenant de droit, elle est naturellement propre à donner en même temps 1 'education morale qui tient si intimement à $I^{\prime}$ enseignement religieux." The state is important because "representant la société dans son ensemble, il est chargé de pouvoir à tous les intérêts, moraux ou matériels, qui réclament son action." Because modern society is so secularly oriented, with the civil and religious aspects of life so distinct, the presence and action of the state "dans le champ de I'instruction publique sont non seulement de droit, mais de devoir."232

Guizot rejected Locke's tabula rasa theory of education. Each individual is born with a given capability. "Education does not give us a character, all that it can do is to turn in a good direction the character which God has given us."233 Each person's capabilities are different, and the educator must realize this. "It is not simply a matter of saying that every rule has its exception. One should rather say that every individual has his rule... Our tailor measures us so that we can have clothes that fit, how can parents do without measuring their children in order that they can be formed and directed?"234 The Enlightenment faith in education as the answer to all problems finds no place in Guizot's thought. Man's reason did not inspire Guizot with the confidence which many eighteenth century men had held.

$$
\begin{aligned}
& 231_{\text {Ibid., pp. } 291-292 .} \\
& 232 \text { Ibid., pp. } 291-292 \text {. } \\
& 233 \text { Quoted by Johnson, Guizot, p. } 101 . \\
& 234 \text { Ibid., p. } 95 .
\end{aligned}
$$


In a speech to the Chamber of Deputies on March 26, 1847, Guizot explained why he opposed a bill to give intellectuals the vote regardless of property qualifications:

Gentlemen, I have infinite respect for intelligence; it is one of the virtues, and it will be one of the titles of honor of our time to have high respect for knowledge and to give it its due. But I myself do not blindly trust intelligence nor do I believe that others should have such trust, least of all in our time. Excessive confidence in human intelligence, human pride, intellectual pride--let us call things by their names--these things are the disease, the cause of a large part of our errors and our evils. Intelligence, as I have had the honor to say in this chamber so frequently, must at all times be guarded, restrained, guided by social conditions. 235

It was not so much the faculty of reason which Guizot doubted, a1though he felt it was too much emphasized. When man followed his reason, he did well. The problem is that man's nature is such that he does not always follow the laws and directives of reason. In a letter to his daughter he wrote,

Quand Dieu a créé 1 'homme, il 1'a créé raisonnable et libre, c'est-à-dire capable de distinguer ce qui est bien de ce qui est mal, et de se décider pour ce qui est bien. La liberté, ma chere enfant, c'est la puissance de choisir le bien, et l'homme tient cette belle puissance de Dieu lui-même. . . Mais comme 1 'homme, en même temps qu'il est raisonnable et libre, est ausi très imparfait et três faible, il a besoin que la bonté, la grâce de Dieu viennent à chaque instant au secours de sa faiblesse et l'aident à lutter contre son imperfection, à laquelle il n'échappe jamais complètement, tant s'en faut. 236

Man has the power to distinguish and to choose the right course, but he does not do so of necessity or even naturally. "In human nature there is at the bottom a grain of barbarism, which looks upon the law of

235 Quoted by Graña, Modernity and Its Discontents, PP. 139-140. From Guizot, Histoire Parlementaire, V, 385-386.

236 de Witt, Dans sa famille, P. 217. 
retaliation as sound justice, and exhibits a blind thirst in the desire for sanguinary punishments."237 Since this is so, man's reason is not to be overestimated as a force for good.

Guizot is still far from dismissing the importance of intelligence. He is most concerned with refuting the pretensious claims of the advocates of reason. "Philosophers estimate too highly the general ideas with which they are possessed; politicians withhold from general ideas the attention and interest they are entitled to demand." 238 Those ideas which have the most powerful hold on men, Guizot argues, are those which "contenant ensemble et confusément une large part de vérité et une large part d'erreur, flattent d la fois les bons et les mauvais instincts des hommes, et ouvrent en même temps la carrière aux nobles espérances et aux mauvaises passions." 239 Man is imperfect. Reason is only part of his makeup. Therefore, philosophy is an imperfect product of man. In a letter to Victor Cousin in 1867, Guizot wrote, "Pour moi, la philosophie n'est qu'une science, c'est-à-dire une oeuvre d'homme, limitée, comme I'esprit humain Iui-même, dans sa sphère et dans sa portée." He contrasted philosophy with religion, which "dans son principe et dans son histoire, est d'origine et d'institution divine. L'une vient de

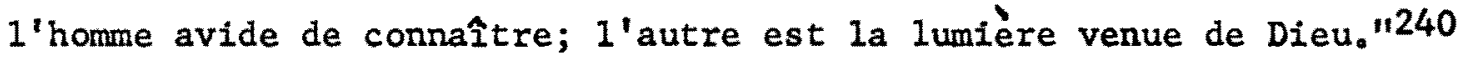

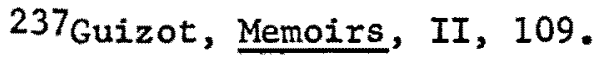

${ }^{238}$ Ibid., I, 199.

239 Guizot, Histoire Parlementaire, I, xvil. This was true for Michelet and Edgar Quinet, whom Guizot described as "two more rare and generous spirits,. . . seduced and attracted by the evil genius of their time into its impure chaos, and who outweigh, in personal value, their ideas and success." Guizot, Memoirs, VII, 173.

$240_{\text {Lettres, }}$ p. 404. 
Man should therefore put much more trust in religion than in philosophy. Because man's reason is, in effect, not perfect, it must come under the scope of the govermment's duties to watch over it. "In becoming more laical, intelligence and science have aspired to greater liberty. This was the natural consequence of their power, popularity and pride, which increased together." Intelligence will never return to an "essentially ecclesiastical" nature, nor will it ever accept anything but an "extensive field of free exercise. But precisely because they are now more laical, more powerful, and more free than formerly, intelligence and science could never remain beyond the government of society."241 Society and government should primarily use "influence" in matters concerning intelligence and science. They should be careful not to alienate the intelligentsia:

Two facts, as I think, are here necessary: one, that the powers devoted to intellectual labour, the leaders of science and literature, should be drawn towards the government, frankly assembled around it, and induced to live in natural and habitual relations with constitutional authority; the other, that the government should not remain careless or 18 norant of the moral development of succeeding generations, and that as they appear upon the scene, it should study to establish intimate ties between them and the state, in the bosom of which God has placed their existence. 242

The power of the intelligentsia should be used by the government to reinforce loyalty to the state, while at the same time the government must respect the liberty which is the prerogative of men in society. "National unity is admirable, assimilation of weights and measures is good, but uniformity of minds sooner or later leads to their weakness

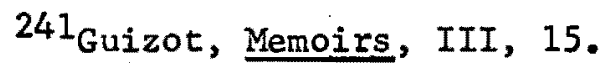
242 Ibid., III, 16. 
or servitude; a result as much to be lamented for the liberty of a nation as for its honour and influence in the world. 1243

The most important fact about Guizot's attitude toward man's reason is his ambivalence. Man was created reasonable but weak. Most of his ideas contain both truth and error. He is subject to the most noble sentiments and the most barbaric passions. Man's reason must be allowed extensive freedom, but it must be restrained short of license. It must be guided and bridled, but it must not be molded so that everyone thinks exactly alike. This ambivalence is of the utmost importance to an understanding of Guizot's feelings about reform. In his Mémoires, he admitted that there "is nothing more difficult and at the same time more important in public life, than to know how at certain moments to resign ouselves to inaction without renouncing final success, and to wait patiently without yielding to despair."244 Just as important as how to act is the problem of when. Guizot felt that the men of his time were often mistaken in their conclusions about both questions. Guizot felt that there "are Divine judgments which human authority ought not to forestall; neither is it called upon to reject them when they are declared by the course of events." 245 The problem is to decide correctly what those judgments are. Guizot was content with his evaluation of situations, but felt many of his contemporaries were in too much

$$
\begin{aligned}
& 243 \text { Ibid., III, } 131 . \\
& 244 \text { Ibid., I, } 304 . \\
& 24{ }^{\text {Ibid.. }} \text { I, } 123 .
\end{aligned}
$$


of a hurry to bring about rapid change. 246 In his lectures on the civilization of Europe, he tried to calm the advocates of precipitate reform. "We, of the present day the told his students], are content with our condition; let us not expose it to danger by indulging in vague desires, the time for realizing which has not come." We must "attach ourselves firmly, faithfully, undeviatingly, to the principles of our civilization--justice, legality, publicity, liberty; and let us never forget, that while we ourselves require, and with reason, that all things shall be open to our inspection and inquiry," that we also "are under the eye of the world, and shall, in our turn, be discussed, be judged."247 Members of a free political society must be realists, he points out. "If you wish for liberty--for the full and glorious development of human nature--learn first on what conditions this is attainable; look forward to its consequences."248 Political spirit must be developed among the members of the society, for the "first and very excellent fruit of the polftical spirit" is the abllity to "see things as they really are." Once we have learned to see only what actually is, "we learn to desire only what is possible; the exact appreciation of facts begets moderation in designs and pretensions." 249

246 Guizot had no trouble resigning himself to reality, so he thought. In his Mémoires he wrote, "Impatience irritates and displeases me. I have need to believe that I am doing what I wish to do; I am willing to accept necessity in order to escape even the appearance of constraint." Guizot, Mémoires, V, 177.

247Guizot, Civilization in Europe, pp. 23-24.

$248_{\text {Guizot, Democracy, p. } 11 .}$

${ }^{249}$ Ibid., pp. 78-79. 
Men must come to realize that while there is Providence in history, bringing progress to human civilization, it is in no hurry. "To Providence, time is as nothing; it strides through time as the gods of Homer through space: it makes but one step, and ages have vanished behind it."250 Providence is concerned with the process of civilization, not with the individuals of society. Individuals must submit to it. "It pleases Providence to bring to nought both the anxieties and the hopes of men."251 There is no cause, says Guizot, no matter how good it is, which has not been tested by cruel reverses, has not struggled for centuries to achieve triumph at last. "Dieu vend cher aux hommes le progrès et le succès." 252 This is not merely an arbitrary and cruel action on the part of Providence, for when a cause has finally triumphed, it is the stronger and safer for the struggles it has been through. Guizot provides an example:

It is one of the chief advantages of liberal institutions, that men long accustomed to their exercise yield slowly to the yoke of emergency, and struggle much before they resign themselves to it, in such manner that reforms and revolutions are only brought about when they are really imperative and recognized beforehand by public opinion strongly tested. 253

Liberal institutions themselves are a long time in being accepted and secured. When they become so, they are a safeguard against hasty or wrong-headed actions by the men of society.

The problem for Frenchmen was that liberal institutions were far from firmly established in France. Therefore, the going was bound to

250 Guizot, Civilization in Europe, p. 17.

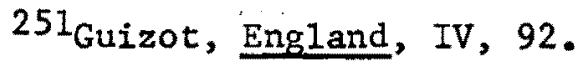

252Guizot, Histoire Parlementaire, I, iii.

${ }^{253}$ Guizot, Memoirs, II, 17. 
be slow, with many setbacks. These difficulties would only be increased if pressures were put on the government for faster reform. 254 Guizot often tried to persuade his contemporaries of this fact, but he still had little faith that they would accept his message. Man is too weak and fallible. "To believe that the free will of man tends to good, and is of itself sufficient to accomplish good, betrays an immeasurable ignorance of his nature." Such an assumption "is the error of pride; an error which tends to destroy both moral and political order; which enfeebles the government of communities no less than the government of the inward man. "255 In his History of the English Revolution, Guizot observed that

a fever of universal ambition, sovereign, impious, sometimes seizes upon men, they imagine in themselves the right and the power to lay hands upon all things, and to reform the world as to them seems fit. Nothing is more absurd, more vain, than these vague extravagances of the human creature, who, treating as chaos the grand system in the bosom of which his place is marked out, essays to erect himself into a creator, and only succeeds in communicating the disorder of his own dreams to whatever he approaches. 256

It is the "glory of man" to be concerned with his situation, to be ambitious rather than passive, but it is the sorrow of man that he is as imperfect and impatient as he is concerned. 257 "It is in the nature of man, even when he has been plunged into such a condition by his own fault Which Guizot feels is quite often the case7, not to desire to remain in it." Man has a need for justice and development which

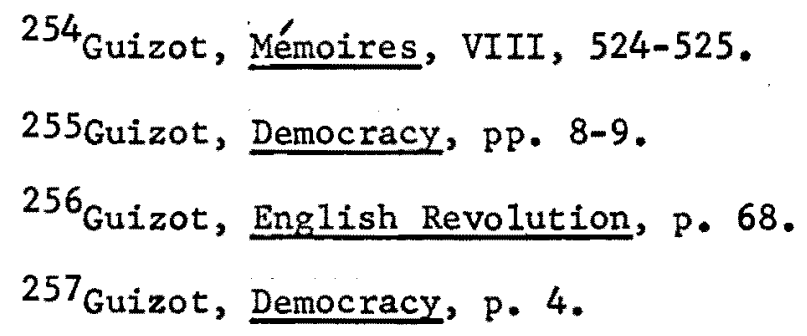


"agitates him even under the yoke of the most brutal selfishness. He feels impelled to reform the material world, and society, and himself; and he labors to do this, though unaware of the nature of the want which urges him."258 Man oscillates between the poles of nobility of thought and barbarity of action. He can be as good as he is quite often bad. "Human nature never goes to the extremity either of evil or good; it passes incessantly from ore to the other, erecting itself at the moment when it seems most likely to fall, and weakening at the moment when its walk seems firmest." 259

The way in which man's weakness is most often manifested is that the people of a society, making the mistake of denying their history, "indulge in the absurd arrogance of believing that [their country belongs to them, and them alone." They assume that "the past, in face of the present, is death opposed to life;

when they reject thus the sovereignty of tradition and the ties which mutually connect successive races, they deny the distinction and pre-eminent characteristic of human nature, its honour and elevated destiny; and the people who resign themselves to this flagrant error, also fall speedily into anarchy and decline; for God does not permit that nature and the laws of His works should be forgotten and outraged to such an extent with impunity. 260

This mistake was particularly evident in Guizot's own time, but it was not new. "The world, from its earliest dawn, in every great crisis, has witnessed the explosion of the same chimeras, the same rebellion of human pride against the arrangements of Providence, the same false

258 Guizot, Civilization in Europe, p. 65.

259 Ibid., Pp. 114-115.

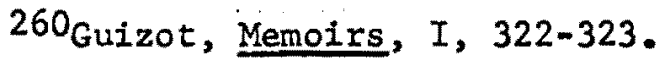


calculations in human nature, and on man's proper share in human Legislations," 261

Fourierism and Saint-Simonism, along with Marxism, which Guizot never really understood, were the foremost of the new follies of mankind. There is, Guizot felt, an internal contradiction in these theories. "At the same time that they defended authority /here he is talking of Saint-Simonism and Fourierism/, they unchained man, and subverted human society in its foundations." These reformers claimed to be contemptuous of anarchy, "but their doctrines and general tendencies aggravated unlicensed perturbation amongst the popular masses, by fomenting the instincts which surrender man up to the jealous thirst of material advantages and the egotism of the passions. "262

By making material concerns and pleasures the center of life, the reformers lower man to the level of the other animals. They "obliterate the human race."263 They ignore the internal man, which is actually the most important part of man. "Nothing can be more anti-Christian than the ideas, the language or the influence of the present race of reformers of the social order." If Communism and Socialism came to predominate, Christianity would "become extinct: if Christianity were more potent, Communism and Socialism would soon sink into the chaotic mass of obscure and forgotten extravagances." 264 The reformers ignore the fact that it is man's soul that "is the stage upon which the events of this world

$$
\begin{aligned}
& 261_{\text {Ibid., II, } 100 .} \\
& 262 \text { Ibid., II, } 196 . \\
& 263 \text { Guizot, Democracy, p. } 30 . \\
& { }^{264} \text { Ibid., pp. } 71-72 .
\end{aligned}
$$


come to play their part; it is not by their own virtue, but merely by their relations to the moral being whose destiny occupies our attention, that events take part in the action." 265 The development of the internal man is of much greater consequence than the external condition of man in society. In his History of Civilization in Europe, Guizot quotes his fellow Doctrinaire, Royer-Collard:

After [man7 has engaged himself to society, there remains to him the noblest part of himself, those high faculties by which he elevates himself to God, to a future life, to an unknown felicity in an invisible world ... We, persons individual and identical, veritable things endowed with immortality, we have a different destiny from that of states. 266

While Guizot's primary complaint against refomers and democrats resulted from their stunting effect on the internal development of man, he was also troubled by their effects on society and government. He defined Democracy as "the development--others would say the explosion-of all the elements of human nature throughout all the ranks and all the depths of society; and consequently the open, general continuous, inevitable struggle of its good and evil instincts." Democracy meant a contest between human nature's "virtues and its vices; of all its powers and faculties, whether to improve or corrupt, to raise or to abase, to create or to destroy, Such is, from henceforth, the social state, the permanent condition of our nation."267 Insofar as Guizot was concerned,

\section{${ }^{265}$ Guizot, Shakspeare and His Times, p. 147. \\ $266_{\text {Guizot, }}$ Civilization in Europe, p. 20. \\ 267 Guizot, Democracy, p. 6. France was not the only nation} troubled by Democracy. Even England was suffering from the malady to an extent. It would "be idle the conceded 7 to deny that the progress of legislation and of public sentiment is forcing England as well as the nations of the continent in the direction of democracy. The alliance between the aristocracy and the democracy is not yet broken; the aristocracy is not dispossessed of its role, in general the authorfty is yet 
it was obvious that the evil side of human nature was by far the most stimulated by Democracy. As a result, the present state of society was chaotic: "Chaos is now concealed under one word--Democracy."268 Democracy is a "fertilizing, but muddy stream, whose waters are never beneficent till the turbid and impetuous current has spread itself abroad and subsided into calmness and purity."269 Calmness and purity would be a long time in returning to France if Democracy came to dominate society, for Democracy is not fitted to govern a society. "The melancholy condition of democratic governments is that while charged as they must be with the repression of disorder, they are required to be complaisant and indulgent to the causes of disorder." Democratic govemments "are expected to arrest the evil when it breaks out and yet they are asked to foster it whilst it is hatching."270 Guizot was unwilling to accept this essentially paradoxical function of a democratic government. A government is to regulate, not cater to the whims of, society. "If what is called love for the people means, to participate in all their impressions, to study their tastes rather than their interests, to be on all occasions ready to think, feel, and act with them,--I admit at once this forms no part of my disposition." He loves

in its hands; it manages the affairs of the country, but it carries them on more and more in sympathy with public sentiment and in obedience to the public will. While still preserving its social rank, it is today the servant, and not the master. The aristocracy governs, the democracy rules, and rules with a mastery too dreaded, and sometimes obeyed with too much docility." Guizot, England, v, 26-27.

$268_{\text {Guizot, Democracy, p. } 2 .}$

${ }^{269}$ Ibid., P. 68.

270 Ibid., pp. 10-11. 
the people, he continues, "with a profound, but at the same time independent and somewhat anxious attachment. I wish to serve them, but am no more disposed to become their slave than to use them for any advantage but their own." He concludes, "I respect while I love them, and this very respect restrains me from deceiving them, or from aiding them to deceive themselves."271 In exile in London, following the February Revolution of 1848 , Guizot wrote that he had "thought of nothing but the situation of my country. The more I reflect upon that, the more I am convinced that the evil which lies at the root of all her evils, which undermines and destroys" her government and her liberties, "her dignity and her happiness, is the evil which I attack;--the idolatry of Democracy."272 In a debate in the Chamber of Deputies in May of 1837, Guizot pointed to the unreasoning and irrational desires of the democrats. "Neither liberty nor the advancement of the working classes have satisfied democracy; it demands levelling; and this is the reason why it has so often and so rapidly ruined the societies in which it has predominated."273 The reformers and democratic leaders commit themselves with

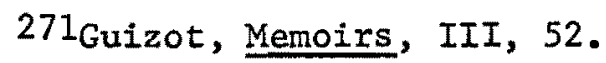

${ }^{272}$ Guizot, Democracy, p. v.

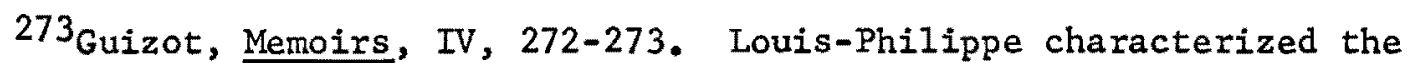
mentality of the July Monarchy when he suggested, "I believe that absolute democracy drives away wealth, because of the jealousy which it inspires, and the lack of effective protection. Democracy tends to the levelling of fortunes, and this tendency is both a check upon the industry which procures wealth, and a cause of disquiet to those who, having already acquired it, wish to keep it. Only a blind respect for law can attract wealth and allow it to show itself and grow without fear. I doubt whether this blind respect can endure in a democracy." Charlotte Touzalin Muret, French Royalist Doctrines Since the Revolution (New York: Columbia University Press, 1933), p. 88. 
pledges which no government can really carry out, without destroying the society:

Devant cette démocratie qu'ils on faite souveraine, ils /le parti républican7 ouvrent des perspectives infinies, ils prodiguent d'immenses promesses de satisfaction et de bonheur; promesses qu'aucun gouvernement, pas plus la République que tout autre, ne peut acquitter; perspectives en contradiction flagrante avec les lois et le cours naturel du monde. 274

When the people who have believed in these promises realize that they can not be fulfilled, anarchy results. Once the perspectives have been opened and the promises left unfulfilled, it becomes very difficult to restore order and nearly impossible to return to liberty.

At the bottom of Guizot's hostility to democracy is the fact that he was basically "an unapologetic bourgeois intellectual."275 The middle classes had played an important role in the history of civilization to the present, and they had an even greater role to play in the future. The party which founded the July Monarchy, Guizot pointed out, "has been called the party of the bourgeoisie,--the middle classes; and this in fact it was, and still is." The rise of the "middle classes in France, incessantly supplied by recruits from the bulk of the population, is the characteristic feature in our history since 1789. Not only have they conqured that ascendancy, but they have justified their claims to

274 Guizot, Histoire Parlementaire, I, cxxx.

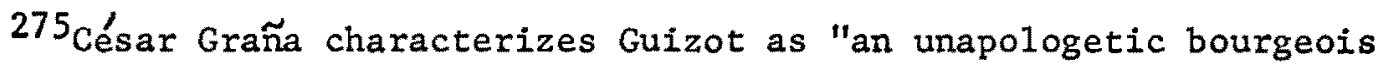
intellectual at a time when pained abhorrence of the bourgeoisie was the official emotion of most writers and artists, whether political or nonpolitical, radical or neo-feudal. In all aspects of his thinking, Guizot was dedicated to the transparent guardianship of class interests." Grana, Modernity and Its Discontents, p. 11. The judgment is overly harsh. Guizot sincerely believed in the historical, progressive role of the bourgeoisie. While clearly a bourgeois, he was far from being a materialist. Materialism was what he saw to be one of the worst aspects of democracy, with its lack of concern for the internal man. 
it." The bourgeoisie has, fallen into numerous and "grievous errors," for which they "have paid so dearly, [but] they have shown that they really possess the qualities that constitute the strength and greatness of a nation. ${ }^{276}$ When called upon in 1830 to institute a new monarchy, the middle classes "brought to that difficult task a spirit of justice and political sincerity of which no succeeding event can cancel the merit."277

Guizot did not gloss over the mistakes of the middle classes. In his History of France, he refuted Siènes' arguments and pointed to the exorbitant demands, and their bad results, of the Third Estate. "In the course of government anterior to 1789 , so far was the third estate from being nothing, [it $]$ had been every day becoming greater and stronger." What Sièyes "and his friends" demanded for it "was not that it might become something but that it should be every thing. This was a desire beyond its right and its strength; and the very Revolution, which was its own victory, proved this." The Revolution, the victory of the Third Estate (by which here is meant the middle classes) brought despotism rather than liberty. When liberty was finally established, hostility toward the middle classes remained among "its foes under the old regimen" as well as among the advocates of "absolute democracy which claimed in its turn to be everything." 278 No class can pretend to be everything in a society which seeks liberty. "The undue ascendancy of one class over another, whether of the aristocracy or the people, becomes tyranny.

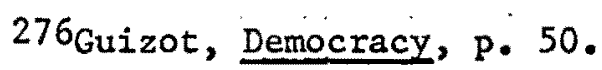

277 Ibid., pp. 50-51.

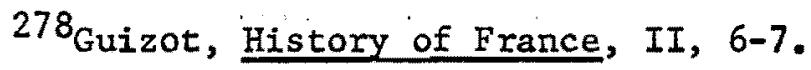


The bitter and continual struggle of either to obtain the upper hand, is in fact revolution, imminently impending or absolutely declared."279 By their very nature, the middle classes will not attempt to dominate French society as a privileged order, as the old aristocracy had done. Their function is a dual one:

To maintain common rights and free movement upwards against the retrograde tendencies of privilege and absolute power on the one hand and on the other against the insensate and destructive pretensions of the levellers and anarchists is now the double business of the middle classes; and it is at the same time, for themselves, the sure way of preserving preponderance in the State in the name of general interests of which those classes are the most real and most efficient representatives. 280

The middle classes do not even dream of becoming a privileged order. "This idle accusation is but an engine of war, erected under cover of a confusion of ideas, sometimes by the hypocritical dexterity, and at others by the blind infatuation of party spirit."281 These classes are not closed. They are open to all with the ability to join them. In a speech to the Chamber of Deputies during the July Monarchy, Guizot expanded on this point: "Have I set limits to this class? Have you understood me to say where it commenced or where it ended? I have simply stated the fact that there exists in the bosom of a great country like France a class which is not tied to manual labor, which does not live from salaries." This class has, "in its thoughts and in its life, liberty and leisure, [it] is able to consecrate a considerable part of its time and its talents to public affairs." It "possesses not only the

$$
\begin{aligned}
& 279_{\text {Guizot, Memoirs, I, } 108 .} \\
& 280 \text { Guizot, History of France, II, } 40 . \\
& 281_{\text {Guizot, Memoirs, I, } 165 .}
\end{aligned}
$$


fortune necessary for such a work, but also the intelligence and the independence without which that work could not be accomplished." It is for these reasons that the middle classes constitute the political class in France. Furthermore, it is "the perfection of our goverment that political rights, limited to those who are capable to exercise them, can be extended in proportion to the extension of capacity within the nation." In our times, he continues, such is "the admirable virtue of this government that it unceasingly encourages the extension of that capacity--so that at the same time that it sets limits to political rights" by means of a property qualification, "at that same moment it works to remove that limit by allowing men to become wealthy and to extend it and thus to raise the entire nation." 282

In every society "which lives and increases there is an internal movement of ascent and acquisition. In all systems that are destined to endure, a certain hierarchy of conditions and ranks establishes and perpetuates itself." This is a simple fact of social organization. "Justice, common sense, public advantage, and private interest, when properly

282Quoted by John B. Wolf, France 1814-1919, The Rise of a LiberalDemocratic Society (New York, Evanston, and London: Harper and Row, Inc., 1963), p. 75. de Tocqueville strongly disagreed with this evaluation of the situation. "In 1830 the wrotel the triumph of the middle class had been definite and so thorough that all political power, every franchise, every prerogative, and the whole government was confined and, as it were, heaped up within the narrow limits of this one class, to the statutory exclusion of all beneath them and the actual exclusion of all above. Not only did it thus rule society, but it may be said to have formed it. It entrenched itself in every vacant place, prodigiously augmented the number of places and accustomed itself to live almost as much upon the Treasury as upon its own industry." The Recollections of Alexis de Tocqueville, translated by Teixeira de Mattos; edited by J. P. Mayer (Cleveland and New York: The World Publishing Company, 1959), pp. 2-3. 
understood, all require a reciprocal acknowledgement of these natural facts of social order."283 The levellers must sooner or later come to accept the necessity for and the naturalness of a social hierarchy. "Les diversités, les inégalités de tout genre, matérielles et morales, naturelles et historiques, persistent et persisteron parmi nous."284 Diversity and inequality will occur in any society and under all laws.285 When this fact is "distinctly perceived and fully admitted" by those who now deny it, "a great step will have been made towards social peace."286 Guizot denies that the middle classes are the enemies of labor. The true enemies of labor are those who wish to destroy the natural "hierarchy of labour, founded on the decrees of God and the free actions of man." These enemies deny the natural, legitimate supremacy of intellectual labor. The real degradation of labor is "the reduction of all labour to the same level."287 The levellers want to lower all of those in the higher echelons of the hierarchy, Guizot feels. He, on the other hand, wants to raise the lower classes up. A man raises himself into the middle classes through labor. "Contempt of labour and pride in idleness are certain signs either that society is under the dominion of brute force, or that it is verging to its decline. Labour is the law which

283 Guizot, Memoirs, I, 283.

284 Guizot, Histoire Parlementaire, I, cxxvii.

285 Guizot, Democracy, p. 40.

286 Ibid. , p. 56.

$287_{\text {Ibid. }}$ pp. 46-47. 
God has enjoined on man."288 It is the duty of the government, and of the middle classes as the central force of government, to allow the free operation and fruition of labor. It is not the duty of government to raise men itself, for that is artificial and can not last nor be truly beneficial to the inner man, which is the ultimate concern for Guizot. Some men "by brains and good conduct make capital and get a good footing upon the ways of competence and progress; others, being dull, or idle, or disorderly, remain in the straightened and precarious condition of existence solely on wages." Throughout the entire social structure, "in the ranks of labor as well as of prosperity, differences and inequalities of position are produced or kept up and coexist with oneness of laws and similarities of rights."

- And these differences, these inequalities in the social positions of men are not matters of accident or violence, or peculiar to such and such a time or such and such a country; they are matters of universal application, produced spontaneously in every human society by virtue of the primitive and general laws of human nature, in the midst of events and under the influence of social systems utterly different. 289

The people of the lower classes, though excluded from the political processes, are not neglected by the political classes. "What can be said at the present time to divide the electors assessed at two hundred francs from those assessed at a hundred and fifty francs?" The elector of

${ }^{288}$ Ibio. , pp. 44-45. Agricultural labor is especially beneficial to the inner development of man: "In agricultural life, man is constantly in the presence of God, and of his power... . It is God who rules the seasons and the temperature, the sun and the rain, and all those phenomena of nature which determine the success or the failure of the labours of man on the soil which he cultivates." The man who cultivates the soil gains "a sentiment of humility as to his power over his own destiny which is thus inculcated upon man; he learns also tranquility and patience." Guizot, Democracy, p. 43.

${ }^{289}$ Guizot, History of France, II, 38-39. 
of "three hundred francs does not exclude the elector of two hundred; he represents him, he protects him, he safeguards his interests, for these interests are his own." Never before in the history of civilization "has a similarity of interest accompanied [such a $\underline{\text { / diversity of }}$ professions and the inequality of conditions." 290 The political classes of France have the same interests as those who can not vote. They will represent those who have not yet reached the level of wealth and achievement so as to qualify for suffrage. This is not tyranny; it is liberty and order:

La politique que nous soutenions et pratiquons ainsi avait son principal point d'appui dans l'influence preponderante des classes moyennes: influence reconnue et acceptée dans l'intérêt général du pays, et soumise à toutes les épreuves, à toutes les influences de la liberté générale . . L Les classes moyenne, sans aucun privilège ni limite dans 1 'ordre civil, et incessament ouvertes, dans l'ordre politiqque, au mouvement ascendant de la nation toute entière, étaient, a nos yeux, les meilleurs organes et les meilleurs gardiens des principes de 1789 , de l'ordre social comme du gouvernement constitutionnel, de la liberté comme de l'ordre, des libertés civiles commes de liberté politique, du progrès comme de la stabilité. 291

${ }^{290}$ Guizot, Histoire Parlementaire, III, 556.

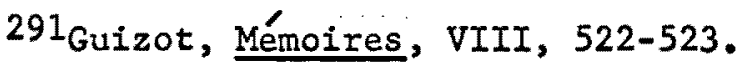


CHAPTER V

PHILOOSOPHY AND RELIGION

Guizot had an aversion to intellectual systems. For this reason, he chose common sense observations and deliberations about man's situation over philosophy and preferred religious faith to theology. Both choices stemmed from what he considered to be the pretensions and pride of the system-building metaphysicians and theologians. His Meditations on the Actual State of Christianity was intended as a refutation of some of the systems offered by theologians and philosophers of the nineteenth century. He is careful to deny any intention of refuting the systembuilders with any system of his own. These Meditations are by no means to form a treatise of metaphysics, he explains. This work "is only an appeal to upright and independent minds; an appeal made to induce them to subject science to the Lsupreme/ test of the human conscience. $"{ }^{292}$ CarefuI men distrust systems which "in the name of pretended scientific truth, would, between the intellectual order and the moral order, between the thought and the life of man, destroy the harmony established by the law of God." 293 What Guizot saw to be a passion for systems in the nineteenth century constituted a war against Christianity, a war which was

292Francois Guizot, Meditations on the Actual State of Christianity And on the Attacks Which Are Now Being Made Upon It (New York: Charles Scribner and Co., N.D.), p. 9.

${ }^{293}$ Ibid., p. 9. 
at the same time historical, political, and philosophical. Christianity's opponent in the war was man's intellectual pride. 294

The most important of the metaphysical constructs with which we dealt was Rationalism, which "extends the pretensions of human science beyond its rights, and beyond its legitimate limits."295 This system, from which most others emerge, concentrates only on the rational side of man. It ignores the non-rational, intuitional, sentimental side of man's nature, In this aspect of Guizot's thought, there are strong traces of Romanticism, though it is the Romanticism of Chateaubriand, not of Byron. Rationalism, and the same is true for Positivism, which Guizot traces to Comte, "does in the intellectual world what it would be doing in the physical world did it deny the reality of night because it only sees the day clearly."296 The philosophers are unable to understand man's non-rational elements and therefore ignore them or deny their existence. This is a grave error, for it is with the non-rational, intuitional side of his nature that man perceives his God. By overemphasizing the rational nature of man, philosophers lead men away from God. Philosophy can never arrive at truth. Truth is embodied in Christianity, and no construct of man can approach it. Guizot illustrates this point by going back to the emergence of Christianity, to show its complete independence from metaphysics: "No natural development of events, either among the Jews or among the Greeks, can account for the existence of Christianity." No matter what progress toward truth was made by the

$$
\begin{aligned}
& { }^{294} \text { Guizot, Mémoires, VII, } 385 . \\
& { }^{295} \text { Guizot, Actual State, p. } 262 . \\
& 296_{\text {Ibid., p. } 264 .}
\end{aligned}
$$


ancients, "there never was a time when there existed not an infinity between their ideas and the ideas of Christianity; and infinity alone can fill up the gulf between [even at the present day7."297 Christianity is not the work of limited men; it is the work of God, the Infinite.

One of the worst mistakes of the nineteenth century philosophers was the attempt to divorce religion and morality, and to find a rational basis for moral actions. While this does not seem as serious as denying morality completely, it will inevitably have the same effect. It is an extremely grave error, "which discards from morality, if not its principle, at least its source and its object, its author and its future. 298 God and Christianity form the true basis for morality. Man is too fallible and weak for any rational basis for moral actions to be of any efficacy. When religion and morality are separated, it is a short step for man to abandon the latter as they have the former. Then men will concern themselves only with earthly pleasures, resulting in the ruin of society and of man. "Thus God and the human race will disappear together." Only animals "bearing the name of men" will remain. 299 Guizot was far from making this mistake in his personal life. At the age of nineteen, he wrote to his mother that God and the religion of Christ, "voila mes guides." The focal point of his actions was Christian morality, and he regarded as dangerous "tout ce qui pourra m'en écarter et comme futile tout ce qui ne m'y ramenera point."300 Three years later, he reaffirmed

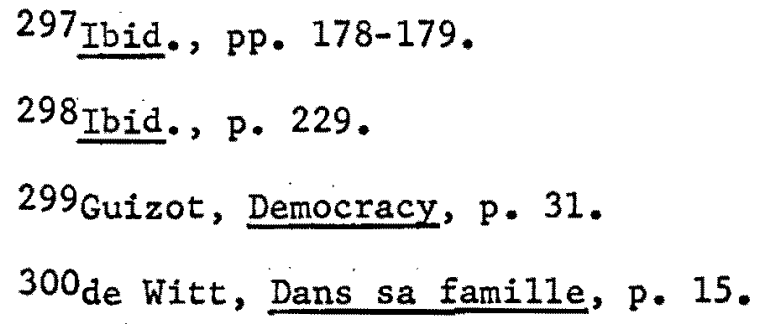


this position in another letter to his mother. The more he progressed, he said, the more he was convinced that religion is necessary to give man all the force and love of the truth which he needs. He was fixmly convinced that without piety and the continual support of God, "L'homme ne saurait effacer la tache originelle dont sa nature est empreinte, ni parvenir à se rendre pur et saint comme on doit l'être, afin d'adorer Dieu en esprit et en vérité." 301 He retained this faith throughout his life, even against the Deism of his first wife, Pauline de Meulan.

To Guizot, it was obvious that no philosophical system, the artificial construct of man, could do for man what Christianity, the work of God, could do. Because Christianity is "sprung from a higher source than man, it alone has a right to succeed, for it alone knows man rightly as he is--as one entire being; it alone satisfies man by furnishing him with a rule for his guidance through life."302 In the minds of men there is a fortunate, "imperishable instinct" that man's destiny is presided over by God, and that this destiny is not completely accomplished in this world. Man naturally believes in God and "invokes Him as his support in the present, his hope in the future."303 If these natural sentiments and instincts of man are not tampered with, there is no problem, but theology and philosophy too often lead man astray:

Never-ending weakness of man's nature, and inevitable imperfection of man's work, even when man is walking in the ways of God. In the midst of awakening Christianity [in the nineteenth century], and of this fervent return to the faith of the Gospel, reappeared

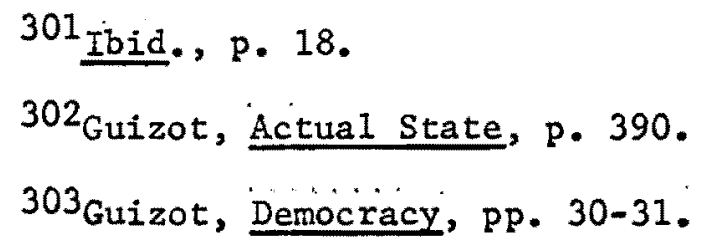


some of the ancient pretensions of theology, and among others the pretension to penetrate the decrees of God and to define the terms of man's salvation. 304

Christianity was man's path to salvation, and that path included the Roman Catholic and the Reformed Churches. Theological disputes and passions are as bad as any other form of blind enthusiasm. Theocratic tyranny is at least as bad as any other tyranny, and because of its dangers for the internal condition of men under that tyranny, it is usually worse. To Protestant and Catholic theologians he pointed out that the soul "does not abdicate the right to its proper and intimate life, because it respects in other souls the rights of that same life; and nothing is more logical or more legitimate than to sustain with fervor the principle of freedom of conscience," while remaining a "true and earnest Christian." 305 The struggles between the various branches of the Christian faith should cease, for neither can win, and, in fact, there is nothing to win from such a struggle. France will never become a Protestant country, nor will Catholicism ever succeed in driving Protestantism from France. Both branches must realize that it "is not between Catholicism and Protestantism that there is a struggle, a struggle of ideas and of power." They both have a common enemy, the core of which is "impiety and immorality." Catholics or Protestants, "priests or congregations, whoever you are, if you are believers you should. . concern yourselves with those who do not believe."306 Within Christianity, Guizot

${ }^{304}$ Guizot, Actual State, pp. 164-165.

305 Ibid., P. 62 .

306Quoted by Johnson, Guizot, p. 397. From Meditations et Études Morales, pp. 79-80. 
favored toleration. While this tolerance may be considered too limited by modern critics, in the perspective of his own time, he was in the vanguard.

While emphasizing liberty of conscience, Guizot did not mean that everyone was on his own to develop his particular, unique religion. There was a need for Church government and for some statement of faith for Christians. "The necessity for a power, for a government over a religious society, as over every other, is implied in the fact of the existence of that society. And not only is government necessary, but it naturally forms itself." When events follow their natural course, "when external force does not mix itself up with them, power always flies to the most capable, to the best, to those who will lead society toward its aim. ${ }^{\text {r } 307}$ This aim is the full and unfettered religious life of the individuals in the society. The secular government must support the ecclesiastical structure. When Guizot became Minister of Public Instruction for the first time, the administration of public worship was taken from that Ministry and attached to the Ministry of Justice, due to Guizot's Protestantism. Guizot considered this shift a mistake:

It was, in my opinion, an error not to form it into a distinct department... In these, our days, and after so many victories, the laical power could not too much conciliate the susceptible pride of the clergy and its leaders ... . To display distrust is to inspire it, and the best mode of living on good terms with the Church, is to acknowledge frankly its importance, and to yield full admission to its place and purpose. 308

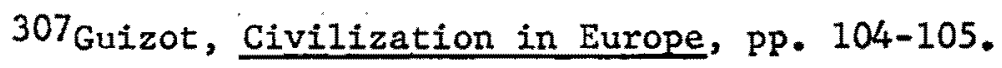

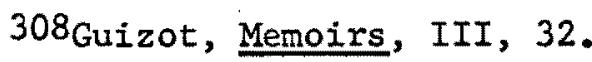


Guizot had serious doubts about separating the State and the Church at that particular time. While such a separation may in theory be both good and practicable, he explained, "it is neither the only good system, nor is it always a practicable system." 309 For France in the nineteenth century, the separation would be too dangerous for both Church and State. The danger which many Frenchmen feared, the domination of the government by the clergy, Guizot felt to be more apparent than real. A much greater danger was that by separating the Church would be condemned to wither away and society would turn from God and religion to earthly pleasures and quick ruin. Thirty years after his death, the separation came about. Guizot's piety was out of fashion.

As to basic dogma, Guizot stressed five as most important to Christianity. These were the Creation, Providence (though he later dropped this as basic, it forms an essential part of Guizot's ideology), Original Sin, Incarnation, and Redemption. Though Guizot's background and religious training was Calvinist, predestination is not found in his religious thought. Liberty is held to be basic to man's nature, as is its counterpart, weakness. Guizot also disagreed with Calvin as to whether the Bible should be read literally. Guizot's concession in this instance to nineteenth century science was a rare one. For example, he still held to the theory of Creation and denied the truth of Darwinian evolution.

Guizot's last years were not consistent with the rest of his life. After pointing out the errors of building systems and insisting on minor distinctions, he spent the 1870's developing his own theology. He was

${ }^{309}$ Guizot, Actual State, p. 184. 
instrumental in getting Thiers to allow a Protestant Synod in 1872 , in which Guizot managed to get his program passed by a majority. The cost was a split in the Reformed Church in France. 310 The aging Guizot mistakenly considered the Synod a triumph for religion. To dwell on these last years is to do disservice to the rest of his life and thought. In 1870, at the age of eighty-three, he had watched the Prussians crush the Empire and saw the brutality of French civil war manifested in the Paris Commune. These tragedies, coupled with the death of friends and members of his family, drove the octogenarian into areas where he would not otherwise have tread. It is religious faith which is basic to Guizot's thought. Theology was an unnatural outgrowth.

310 For a more complete treatment of Guizot's role in the Protestant Synod of 1872 and the resulting split see Johnson, Guizot, chaptex 8, "Protestantism." 
SELECTED BIBLIOGRAPHY

Barnes, Harry Elmer. A History of Historical Writing. 2nd ed. New York: Dover Publications, Inc., 1963.

Berens, Lewis H. The Digger Movement in the Days of the Commonwealth. London: Holland Press and Merlin Press, 1961.

Brailsford, H. N. The Levellers and the English Revolution. Stanford: Stanford University Press, 1961.

de Sauvigny, Guillaume de Bertier. The Bourbon Restoration. Translated by Lynn M. Case. Philadelphia: University of Pennsylvania Press, 1966.

de Tocqueville, Alexis. The Recollections of Alexis de Tocqueville. Translated by Teixeira de Mattos. Edited by J. P. Mayer. Cleveland and New York: The World Publishing Company, 1959.

de Witt, Mme. Guizot. Monsieur Guizot dans sa famille et avec ses amis. Paris: Librairie Hachette et cie, 1880.

Duveau, Georges. 1848: The Making of a Revolution. Translated by Anne Carter. New York: Vintage Books, 1968.

Gooch, G. P. History and Historians in the Nineteenth Century. Boston: Beacon Press, 1959 .

Graña, César. Modernity and Its Discontents: French Society and the French Man of Letters in the Nineteenth Century. New York, Evanston, and London: Harper \& Row, 1967.

Guizot, François Pierre Guillaume. The History of Civilization in Europe. Transláted by Wm. Hazlitt. New York: A. L. Burt, N. D.

- A Popular History of England From the Earliest Times to the Accession of Victoria. Translated by M. M. Ripley. 5 vols. Boston: C. F. Jewett Publishing Co., 1876.

History of the English Revolution of 1640, From the Accession of Charles I to His Death. Translated by Wm. Hazlitt. London: Be11 \& Daldy, 1870 .

- Democracy in Erance. London: John Murray, 1849. Though this was written immediately after the Revolutions of 1848 , it is more than a mere polemic, and is of lasting importance for those wishing to understand Guizot. 
Guizot, François, and de Witt, Mme. Guizot. The History of France from the Earliest Times to 1848. Translated by Robert Black. 8 vols. New York: Worthington Co., N. D.

Guizot, François. Memoirs to Illustrate the History of My Time. Translated by J. W. Cole, Esq. 8 vols. London: Richard Bentley, 1858. Only volumes I, II, III, and IV of this edition were used.

- Mémoires pour servir à l'Histoire de mon temps. 8 vols. Paris: Michel Levy Freres, 1872. Only the last four volumes of this edition were used in this study.

- Histoire Parlementaire de France, Complement des Memoires pour servir a l'Histoire de mon temps. 3 vols. Paris: Michel Levy Frères, 1863.

- The Fine Arts: Their Nature and Relations. Translated by George Grove. London: Thomas Bosworth, 1853.

- Shakspeare and His Times. London: Richard Bentley, 1852.

- Meditations on the Essence of Christianity and on the Religious Questions of the Day. New York: Charles Scribner \& Co., 1865 .

- Meditations on the Actual State of Christianity and on the Attacks Which Are Now Being Made Upon It. New York: Charles Scribner \& Co., N. D.

- Lettres de M. Guizot à sa famille et à ses amis. Edited by Mme. Guizot de Witt. Paris: 1884.

Hegel, G. W. F. Reason in History A General Introduction to the Philosophy of History. Translated by Robert S. Hartman. Indianapolis and New York: The Bobbs-Merrill Company, Inc., 1953.

Johnson, Douglas. Guizot: Aspects of French History 1787-1874. London: Routledge \& Kegan Paul, 1963.

Koepke, Robert Louis. "Francois Guizot and the Formation of a Conservative Party in France, 1840-48." Unpublished Ph.D. dissertation, Stanford University, 1967.

Mellon, Stanley. The Political Uses of History: A Study of Historians in the French Restoration. Stanford: Stanford University Press,

Morazé, Charles. The Triumph of the Middle Classes: A Political and Social History of Europe in the Nineteenth Century. Translated by George Weidenfeld and Nicolson Ltd. Garden City, New York: Doubleday and Company, Inc., 1966.

Muret, Charlotte Touzalin. French Royalist Doctrines Since the Revolution. New York: Columbia University Press, 1933. 
$0^{\prime}$ Connor, Sister Mary Consolata. The Historical Thought of Erancois Guizot. Washington, D. C.: The Catholic University of America Press, 1955.

Pouthas, Charles-H. La jeunesse de Guizot (1787-1814). Paris: Librairie Felix Alcan, 1936.

Resnick, Daniel P. The White Terror and the Political Reaction After Waterloo. Cambridge: Harvard University Press, 1966.

Sainte-Beuve, C.-A. Nouveaux Lundis. Paris: 1875.

Stem, Fritz, ed. The Varieties of History from Voltaire to the Present. Cleveland: The World Publishing Company, 1956.

Talman, J. L. Romanticism and Revolt, Europe 1815-1848. N. P.: Harcourt, Brace \& World, Inc., 1967.

Voltaire. Philosophical Letters. Translated by Ernest Dilworth. Indianapolis, Kansas City, and New York: The Bobbs-Merrill Company, 1961.

Wolf, John B. France 1814-1919 the Rise of a Liberal-Democratic Society. New York, Evanston, and London: Harper \& Row, Inc., 1963.

Woodward, E. I. Three Studies in European Conservatism.-Metternich: Guizot: the Catholic Church in the Nineteenth Century. London: Constable \& Co., Lt., 1929. 